\title{
PRELIMINARY RESULTS OF A PILOT STUDY CONDUCTED BETWEEN ST. JOSEPH, MICHIGAN AND MICHIGAN CITY, INDIANA
}

\author{
Foster, D. S., Brill, A. L., Brown, C. L., Folger, D. W. \\ U. S. Geological Survey, Woods Hole, MA 02543 \\ Andreasen, Christian, Carroll, D. G., Seidel, Dean, Fromm, Gregory \\ National Ocean Service, NOAA, 11400 Rockville Pike \\ Rockville, Md. 20852
}

A Cooperative Undertaking by the USGS-NOAA Office for Mapping and Research

U. S. Geological Survey Open File Report 92-348

This report is preliminary and has not been reviewed for conformity with U. S. Geological Survey editorial standards and stratigraphic nomenclature. Any use of trade names is for descriptive purposes only and does not imply endorsement by the USGS. 


\section{CONTENTS}

Page No.

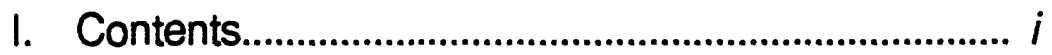

II. Introduction................................................................ 1

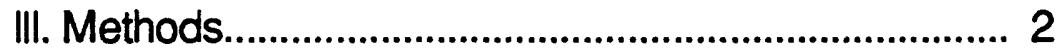

IV. Results and discussion..................................... 5

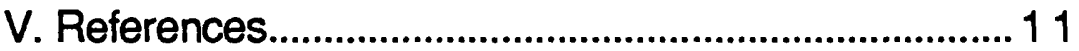

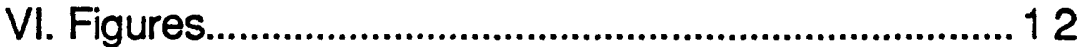

Fig. 1 Map showing 1991

NOS-NOAA echo

sounding tracklines.

Fig. 2 Map showing USGS geophysical tracklines collected in $1991 \ldots . . . . . . .14$

Fig. 3 Map showing bathymetry interpreted from NOS 1991 echo sounding 15

Fig. 4 Map showing smaller scale 1991 NOS bathymetry 16

Fig. 5 Map showing 1991

bathymetry from airborne laser data in the same area as in Fig. 4

Fig. 6 Map showing NOAA depth sounding profiles collected in 1945-46. 
Fig. 7 Map showing NOAA depth sounding profiles collected in 1964-65

Fig. 8 Map showing difference in lake depth between NOAA 1945-46 and 1964-65 surveys....... 20

Fig. 9 Map showing difference in lake depth between NOS 1964-65 and 1991 surveys

Fig. 10 Map showing difference in lake depth between NOS 1945-46 and 1991 surveys 22

Fig. 11 More detailed map of the difference in depth between NOS $1945-46$ and 1991 surveys 23

Fig. 12 Map showing interpretation of USGS seismic reflection survey 24

Fig. 13 Geologic cross-sections showing seismic stratigraphy 25

Fig. 14 Map showing bottom sediment type based on sidescan sonar, sample data, and 1991 NOS bathymetry

Fig. 15 Map showing locations and composition of bottom sediment samples collected in 1991

Fig. 16 Map showing sidescan sonar mosaic and NOS bathymetry 
near Lakeside, MI

Fig. 17 Map showing the interpretation of bottom type from sidescan sonar and sample data with bathymetry near Lakeside, MI

Fig. 18 Map showing sidescan sonar mosaic and NOS bathymetry near Shoreham, MI 30

Fig. 19 Map showing sidescan sonar mosaic and NOS bathymetry near Grand Mere, MI................................ 31

Fig. 20 Map showing the interpretation of bottom type from sidescan sonar and sample data with bathymetry near Shoreham, MI.

Fig. 21 Map showing the interpretation of bottom type from sidescan sonar and sample data with bathymetry near Grand Mere, MI

VII. Appendix A-Workshop agenda....................... 34

VIII. Appendix B-Attendees...................................... 37

IX. Appendix C-Acknowledgments........................46

Cover Photo-Bluff erosion undermining foundation of a house south of St. Joseph, MI. Taken by D. W. Folger, Spring, 1991 


\section{INTRODUCTION}

The National Oceanic and Atmospheric Administration, in cooperation with the U.S. Geological Survey, has been tasked by the $U$. S. Congress to update the obsolete shoreline maps of the U. S. Great Lakes. Because of intense erosion, especially during the high water periods of the 1970's and 1980's, many existing maps are no longer useful for planning the environmental, recreational, and industrial development of the shores of the U. S. Great Lakes.

To provide the necessary comprehensive information that will serve as the basis for rational development and management of this great resource, in 1991, NOAA and USGS, with researchers from the University of Michigan, Michigan State University, and Western Michigan University, carried out a pilot study of the southwest shoreline of Michigan. Bathymetric, geophysical, and geologic data were collected as far as $10 \mathrm{~km}$ offshore. Results of these studies show that the offshore sand and beach sand that provide protection for the underlying glacial till and for the bluffs along the margin of the lake, are thin to non-existent in many areas. Near St. Joseph, MI, our data show that, locally, as much as $4 \mathrm{~m}$ of the lake bottom has been removed by geologic processes during the past 50 years and the adjacent beach and bluff have been severely eroded (see cover photo).

On March 17, 1992 the first Regional Great Lakes Workshop was held at Western Michigan University to review the progress being made under funding for this study. Forty-two people attended from Federal and State Agencies, academia, and private industry. Fifteen presentations and discussion sessions were held during the one-day workshop. Included in this Open File Report is only the material presented by NOAA and USGS. The University data will be presented after the cooperative agreements have been completed. The agenda and attendees are included in Appendices A and B.

The maps and cross-sections shown in this report and those completed by the contractors will be incorporated into a CD-ROM that will include the data on which they are based. They then will be published in a USGS Miscellaneous Investigations format. 


\section{METHODS}

\section{National Ocean Service (NOS)}

The bathymetric data for this project were collected with basic NOS surveying methods and equipment. Linespacing was expanded to 500 meter intervals and extended from the $1.5 \mathrm{~m}$ depth curve out to $6 \mathrm{~km}$ from the shoreline (fig. 1). Three additional areas of supplemental hydrography were also completed to complement sidescan sonar mosaic surveys carried out by USGS.

NOAA Launch 1292, a 7-m MonArk boat, was used to collect data. The data acquisition system (DAS) used was the Coast and Geodetic Survey (C \&GS) standard small boat single beam Hydrographic and Acquisition Processing System (HDAPS). This, coupled with PCbased DAS and ASHTECH navigation software, provided both bathymetric data and Differential Global Positioning System (DGPS) capabilities.

Sounding equipment consisted of an Innerspace Model 448 dualfrequency echo-sounder. The echo-sounder had appropriate instrument and velocity corrections applied. Actual water level heights were applied during processing of the final smooth sheet.

DGPS (Differential Global Positioning System) was used as the method of positioning for all hydrographic data on this project. ASHTECH receivers were used at the base and remote stations. To meet the requirements for daily system check, procedures as recommended by a memorandum from the Nautical Charting Research and Development Laboratory were used. An increase in the daily rate of data acquisition from 30 to 50 percent was realized using DGPS over convential positioning systems.

The final smooth sheets for this project, at a scale of $1: 20,000$, met all necessary NOS requirements. These reconnaissance surveys are registered as D-surveys and filed as blueprints in the Mapping and Charting Branch of NOS.

The addition of laser bathymetry to this project was proposed by 
C\&GS. The Canadian Hydrographic Service (CHS) had a system (the LARSEN 500 Scanning Lidar Bathymeter) in operation during July, 1991, in the Great Lakes. C \& GS, through a cooperative arrangement with the CHS, funded 1 day's use of the laser system.

The laser system was built by Optech, Inc., of Downsview, Ontario, and operated under license to Terra Surveys. The acquisition system scans with pulses of infrared and blue/green lasers. The infrared laser reflects from the water surface and the blue/green laser from the bottom. Returning light is detected and the elapsed time between the two returns is used to compute water depth. Aircraft position was determined using ASHTECH XII receivers operating in differential mode. The differential corrections were transmitted from the base station to the aircraft with UHF radio data link. For each laser scan the acquisition system records six different observations on magnetic tape. The LARSEN 500 system can generate up to 70,000 soundings/hour. The collection of 10 flight lines of laser bathymetry was accomplished smoothly in one afternoon. The efficiency with which such a large volume of data were collected confirmed the usefulness of the airborne system for shallow water erosion studies as a supplement to classic hydrographic surveying. The laser bathymetric data were reduced to vertical soundings and corrected for lake levels by Terra Surveys.

The laser-derived soundings were plotted on 1:20,000 and 1:15,000scale field sheets. The full density data set of all clean soundings was stored on magnetic tape. Terra Surveys also supplied high resolution video tapes along the flight lines. The final product, with overlapping swaths, consisted of soundings spaced at approximately $20-m$ intervals.

NOS contributions also included a topographic survey of New Buffalo, Michigan. A prototype map was produced at a scale of 1:5,000 and portrays topographic relief from the shoreline to an elevation above the predicted 500-year flood line. Contours are depicted at onemeter intervals to at least the 6-m contour line. The map is based on analytical stereo photogrammetry from controlled aerial photographs collected on June 4, 1991. The source photography and toographic map will be maintained on file in the Photogrammetry 
Branch of NOS.

\section{U.S. Geological Survey}

The geophysical and geologic data presented were collected during 1991 aboard the Hydrographic Survey Company's 20-m long Research Vessel NEPTUNE, and bottom sediment samples were collected from Western Michigan University's 7-m long research vessel GEO 1. A total of 12 transects were run roughly normal from the shore as far as $10-12 \mathrm{~km}$ lakeward, and one tieline was run $1 \mathrm{~km}$ offshore (fig. 2). Three areas off Shoreham, Grand Mere, and Lakeside, were surveyed with sidescan sonar imagery. Line spacing for these surveys was about $100 \mathrm{~m}$ (fig. 2), close enough to provide the overlap necessary to provide complete sonar coverage.

Sidescan sonar data were collected with a $500 \mathrm{kHz}$ Klein System and recorded on a QMIPS digital acquisition system. High resolution seismic reflection data were collected on an ORE narrow-band transducer with an output of $10 \mathrm{~kW}$ at a frequency of $3.5 \mathrm{kHz}$ for shallow penetration and a Huntec broad-band boomer seismic profiling system with a power output of $135-500$ joules for deeper penetration. A $200 \mathrm{kHz}$ Odem echosounder recorded analog as well as 10-s average digital records. Speed of the vessel during profiling was most often $2 \mathrm{~m} / \mathrm{s}$. The R/V Neptune's position was determined with Miniranger Falcon IV backed-up with GPS. Differential GPS was used for positioning the R/N GEO 1, and bottom sediment samples were collected with a Shipek grab. 


\section{RESULTS AND DISCUSSION}

\section{Bathymetry}

A bathymetric map of the study area (fig. 3), contoured from the 1991 NOAANNOS sounding data (fig. 2), shows the physiographic form of the lake floor and provides a base for geologic framework mapping. The bathymetry shows a relatively steep slope (about $1: 100)$ of the lake floor between the shoreline and the $10-\mathrm{m}$ isobath. The slope of the lake floor is more gradual (about 1:450) in deeper water. However, there are anomalies in the nearshore bathymetry that deviate from this common lake-floor profile. A shoal off Lakeside, Michigan rises about $5 \mathrm{~m}$ above the surrounding lake floor. South of this shoal, between water depths of $10-15 \mathrm{~m}$, the lake floor is relatively flat, and contours define many enclosed depressions on the bottom. Another bathymetric anomaly occurs where there is a lakeward bulge in the 10 and $20 \mathrm{-m}$ contours between Grand Mere and St. Joseph, Michigan. The shoal at Lakeside, Michigan occurs where bedrock (Devonian shale) crops out at the lake floor (Meisburger and others, 1979). The flat area south of this shoal and the bulge in contours between Grand Mere and St. Joseph, Michigan may be related to underlying bedrock structure.

Two detailed bathymetric maps were contoured for an area near New Buffalo, Michigan, one from acoustic soundings (fig. 4) collected by NOAA/NOS in 1991 and the other (fig. 5) from an airborne laser survey conducted by Terra Surveys, Inc. The bathymetric map generated from the closely spaced $(20 \mathrm{~m})$ depth measurements of the laser survey resolves nearshore sand bars that are only partially resolved in the acoustic data. A map could be constructed only to a water depth of $15 \mathrm{~m}$ because laser penetration was limited by turbidity. A plume of turbid outflow from New Buffalo, MI was clearly visible on the video tapes, and, as expected, the plume generated a "holiday", or area of missed depths, in the laser sounding data.

Two bathymetric data sets (National Geophysical Data Center, 1987) from surveys conducted in 1945-1946 (fig. 6) and 1964-1965 (fig. 
7) were used to illustrate changes in water depth, i.e., net erosion or net accretion of lake-bottom sediment. Figure 8 shows the changes in water depth between 1945-1946 and 1964-1965. This map shows that relatively minor changes $( \pm 1 \mathrm{~m}$ ) have occurred over most of the study area. Differences in depth of $\pm 1 \mathrm{~m}$ between the time-series data may not be accurately resolved because of the uncertainty of comparing data points that do not precisely coincide. The validity of such a comparison depends on how accurately our surface models portray the true surface. However, relatively significant areas of lake-bottom have eroded close to shore south of St. Joseph to Grand Mere State Park. As much as $4 \mathrm{~m}$ of lake-bed have been eroded, resulting in a steepened lake floor profile nearshore. Just north of St. Joseph and the jetties at the mouth of the St. Joseph River, net accretion of sediment has resulted in shallower depths.

A map showing change in water depth from 1964-1965 to 1991 (fig. 9) again shows that relatively minor changes $( \pm 1 \mathrm{~m})$ have occurred over much of the area. The nearshore area south of St. Joseph has been eroded further since 1964-1965, although not as much as during the 1945-1946 to 1964-1965 period; in some areas even net accretion has taken place. The accretion, immediately south of the jetties at St. Joseph, may have resulted from beach nourishment carried out by the U. S. Army Corps of Engineers (L. Parsons, personal commun., 1992). Also, the difference map shows significant erosion close to shore south of the entrance to New Buffalo Harbor for a distance of about $5 \mathrm{~km}$.

The net change in water depth between 1945-1946 and 1991 (fig. 10) shows that most of the lake floor has changed less than $\pm 1 \mathrm{~m}$, although erosion of $1 \mathrm{~m}$ or less is more predominant than accretion.

In summary, the map shows that significant erosion has occurred south of St. Joseph and New Buffalo harbor jetties which are barriers to the southerly littoral drift. In 1903, the harbor jetties were constructed to their present length of $960 \mathrm{~m}$ north of the channel and $1200 \mathrm{~m}$ south of the channel (Buckler, 1981). A detailed lake bottom difference map for the area between St. Joseph and Grand Mere State Park (fig. 11) shows the amount of erosion of the lake floor in an area where severe coastal bluff erosion (Buckler, 1981) has occurred. 
Seismic Stratigraphy

A geologic map (fig. 12) and cross sections (fig. 13, a-d) were generated from interpretation of the seismic-reflection profiles. In the survey area, the bedrock surface (Devonian shale) is overlain by glacial till of the Wadsworth Member. Holocene lacustrine deposits, which include deep water lacustrine mud and nearshore sand, overlie the till.

In the subbottom, the upper surface of the Devonian shale appears as a weak reflection in high-resolution seismic profiles, apparently as a result of the low acoustic impedance contrast between the shale and the overlying unconsolidated sediment. In some areas we were unable to identify the bedrock reflector. However, seismic profiles were useful in mapping areas where shale crops out at the lake floor (fig. 12) forming, for example, the shoal (fig. 2) off Lakeside, Michigan (figs. 12 and 13 a,b). Less extensive outcrops occur within $3 \mathrm{~km}$ of shore (figs. 12 and 13c) where the sediment overburden is commonly thin. Further offshore, the till and lacustrine deposits thicken.

The glacial till appears as a massive seismic unit that contains scattered internal reflections. Till occurs in the subsurface throughout most of the study area but occasionally crops out at the lake floor within $6 \mathrm{~km}$ from shore. It is difficult to define the till unit close to shore, where shale is close to the surface and unconsolidated sediment is thin.

A thick Holocene lacustrine sediment wedge forms an acoustically transparent seismic unit that contains some continuous parallel reflections. This thick wedge of sediment thins shoreward and feathers out within $3-6 \mathrm{~km}$ from shore (figs.12 and 13a-d). Seismic profiles did not always define the total thickness of the lacustrine sediment wedge because interstitial gas attenuated the seismic signal. Where seismic signals did penetrate the whole unit, the wedge is as thick as $14 \mathrm{~m}$. Internal reflections are parallel to the lake floor in the southern and northern part of the study area; 
however, in the center of the area, internal reflections are truncated at the lake floor (fig. 13b,c). In this area an ancient embayment in the shoreline was present when lake level was higher during the Nipissing stage or about $5 \mathrm{ka}$. Nipissing age lacustrine deposits have been mapped onshore in the embayment area (Grahame Larson, personal communication, 1992). During the Nipissing stage, the lacustrine wedge probably extended into the old embayment. The subsequent drop to modern lake levels resulted in wave-base erosion of the lacustrine wedge and truncation of internal reflectors.

Shoreward of the lacustrine wedge is a thin (about $1 \mathrm{~m}$ ) blanket of Holocene sand that appears as a transparent seismic unit. The base of the sand blanket is seen as a reflection at the sand-till or sandshale interface. The seismic profiles show that windows in the sand occur in places where till and shale crop out. In places, the sand blanket, based on grab samples (fig. 15), is present, but is too thin to be resolved on seismic profiles. The Holocene sand thickness can be resolved on the shoreward end of most shore-perpendicular lines (fig. 13a-d).

\section{Bottom Sediment Type}

Bottom sediment type was mapped (fig. 14) from sidescan sonar data and bottom sediment samples (fig. 15). The predominant bottom sediment type is very fine sand to fine sand, which corresponds to the Holocene lacustrine sand blanket and the shoreward part of the lacustrine sediment wedge (fig. 14). Surface sediment of the wedge grades to sandy silt and muddy sand in deeper water. Where the Holocene sand blanket is absent, bottom sediment type consists primarily of medium to coarse sand and sandy gravel; less frequently, sandy-silty clay is exposed at the lake floor (figs. 14 and 15). We interpret the medium-coarse sand bottom as a lag deposit derived from erosion of till at the lake floor and the sandy-silty clay as the till. The Holocene sand blanket covers approximately $60 \%$ of the lake floor in the area between St. Joseph and Grand Mere State Park. South of this area, the sand blanket is less patchy (fig. 14). As observed on the seismic profiles, bedrock crops out at the lake floor, and was mapped as shale on the bottom sediment type map (fig. 14), although patchy till and sand may cover the shale. 


\section{Detailed Surveys}

A sidescan sonar mosaic, 500-m wide and 2500-m long, was constructed of the shoal area off Lakeside (figs. 3 and 16). Four bottom types were mapped based on the sidescan sonar, $3.5 \mathrm{kHz}$ seismic, and sediment sample data (fig. 17). In general, the contrast seen in the sidescan sonar mosaic (fig. 16) is related to acoustic backscatter strength; high backscatter is black and low backscatter is white.

The shoal is underlain by shale, and the exposed north-northwest bedding and fractures within the shale produced a distinctive pattern on the sidescan mosaic (fig. 16). The shale has been cored in this area by Meisburger and others (1979). Between the shoal and the nearshore slope, within a bathymetric trough, the sidescan mosaic has a relatively dark appearance, the result of high acoustic reflectance (fig. 16) from a rough, coarser-textured bottom. The bottom is composed of till which crops out through a thin layer of lag deposits.

Most of the nearshore slope is covered by a blanket of very fine sand to fine sand (fig. 17) which produces a weak acoustic reflection (light area) on the sidescan mosaic (fig. 16). Seismic profiles show that the sand blanket is thin (about $1 \mathrm{~m}$ ) and overlies a wedge of till that thickens from the till exposure in the bathymetric trough towards shore. The till wedge may be part of the Lake Border Moraine that projects offshore from the Lakeside area (Grahame Larson, personal communication, 1992).

Two sidescan mosaics, each approximately 800-m wide and 5000-m long, were constructed for an area off Shoreham, Michigan (fig. 18) and just north of Grand Mere State Park (fig. 19). At the Shoreham mosaic area, about $4 \mathrm{~km}$ south of the harbor entrance at St. Joseph, sixty percent of the bottom is covered by very fine sand to fine sand, light areas on the mosaic, and 40 percent of the bottom is exposed till or lag deposits over till, dark areas on the mosaic (figs. 18 and 20). The Grand Mere mosaic is located about $11 \mathrm{~km}$ south of the harbor entrance at St. Joseph. There, the very fine-fine sand blanket 
is more extensive, covering 80 percent of the mosaic area, than for the Shoreham mosaic area (figs. 19 and 21). The lakeward end of the mosaic is almost all very fine sand to fine sand and muddy sand below water depths of $19 \mathrm{~m}$. The $19-\mathrm{m}$ isobath is where the Holocene lacustrine sediment wedge feathers out. The northtrending patches on the mosaic, in water depth greater than $19 \mathrm{~m}$, may relate to the truncation of internal bedding of the lacustrine wedge (fig. 19). In water depths of less than $19 \mathrm{~m}$, dark linear patches, areas of exposed till and lag deposits, trend northwest; the patches cover twenty percent of the mosaic area (figs. 19 and 21). The areas of lag deposits and till often occur in slight bathymetric depressions in both mosaic areas. We suggest that wave-induced currents scour the lake floor resulting in erosion of the till and generation of coarse lag deposits. This process appears to be more active for the area off Shoreham, where, historically, coastal bluff (Buckler, 1981) and lake bed (fig. 11) erosion have been severe. The harbor jetties to the north of this area have effectively trapped some of the southerly littoral drift which has resulted in a sediment starved nearshore area to the south; sand cover, therefore, is not sufficient to protect the till from erosion. 


\section{REFERENCES}

Buckler, 1981, Rates and implications of bluff recession along the Lake Michigan shorezone of Michigan and Wisconsin: unpublished PhD thesis, Michigan State University, E. Lansing, Michigan, 188 p.

Meisburger, E. P., Williams, S. J., and Prins, D. S., 1979, Sand resources of southeastern Lake Michigan: U. S. Army Corps of Engineers Miscellaneous Report No. 79-3, 61 p.

National Geophysical Data Center, 1987, NOS hydrographic databaseexpanded digital bathymetric data for coastal waters: NOAA National Geophysical Data Center Announcement 87-MGG-12, 8p. 
FGURES 


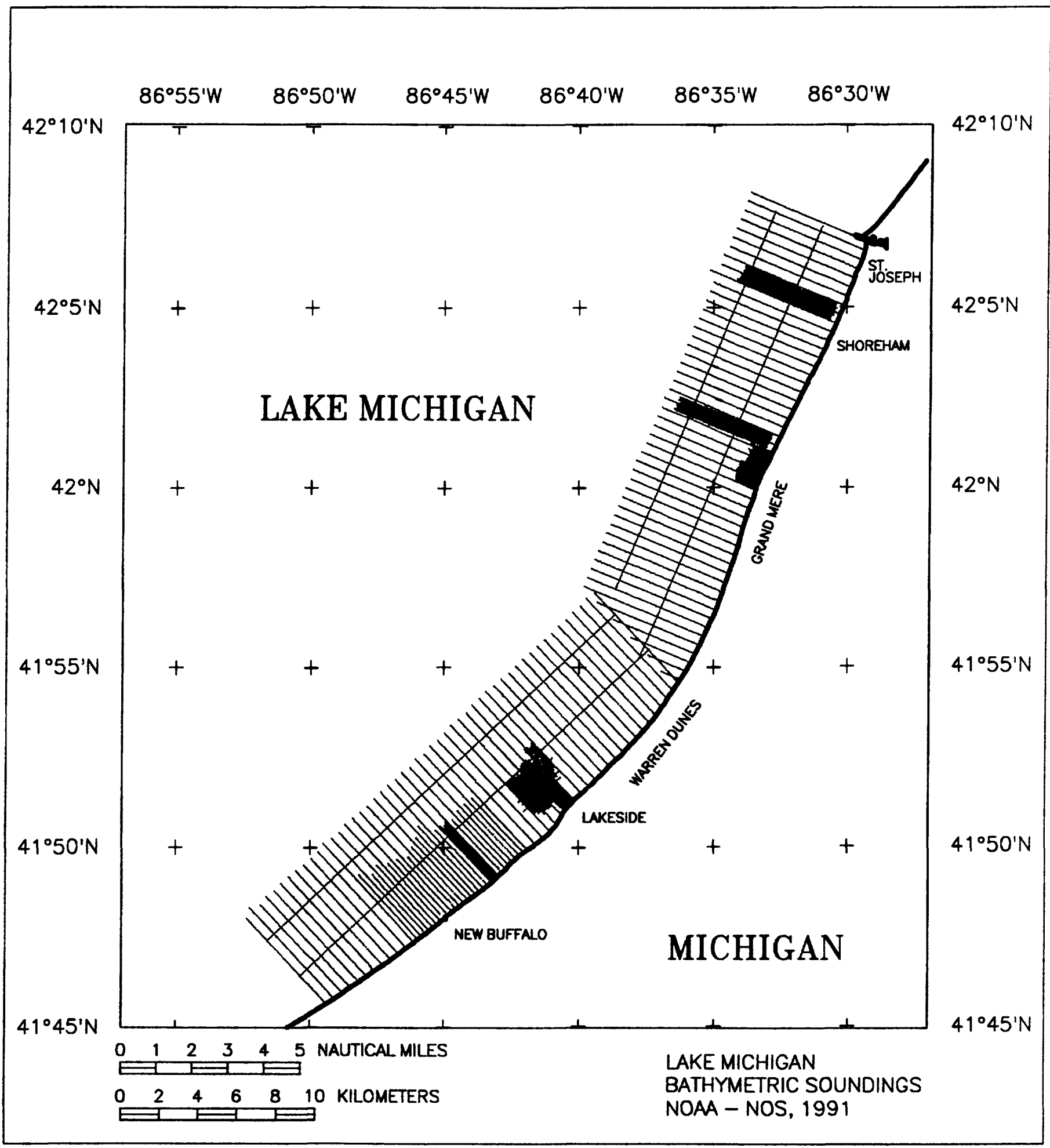

Figure 1. Lake Michigan 1991 NOAA-NOS echo sounding tracklines. In solid green areas tracklines are closer together.
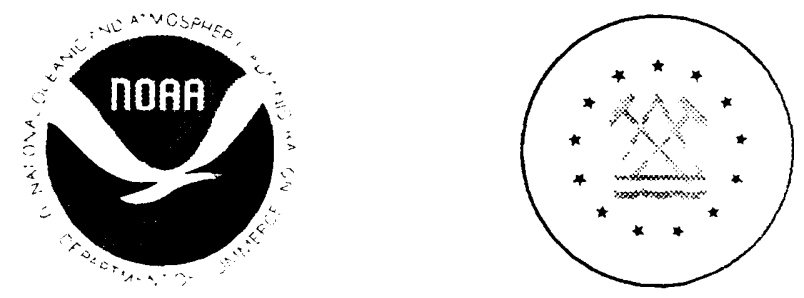


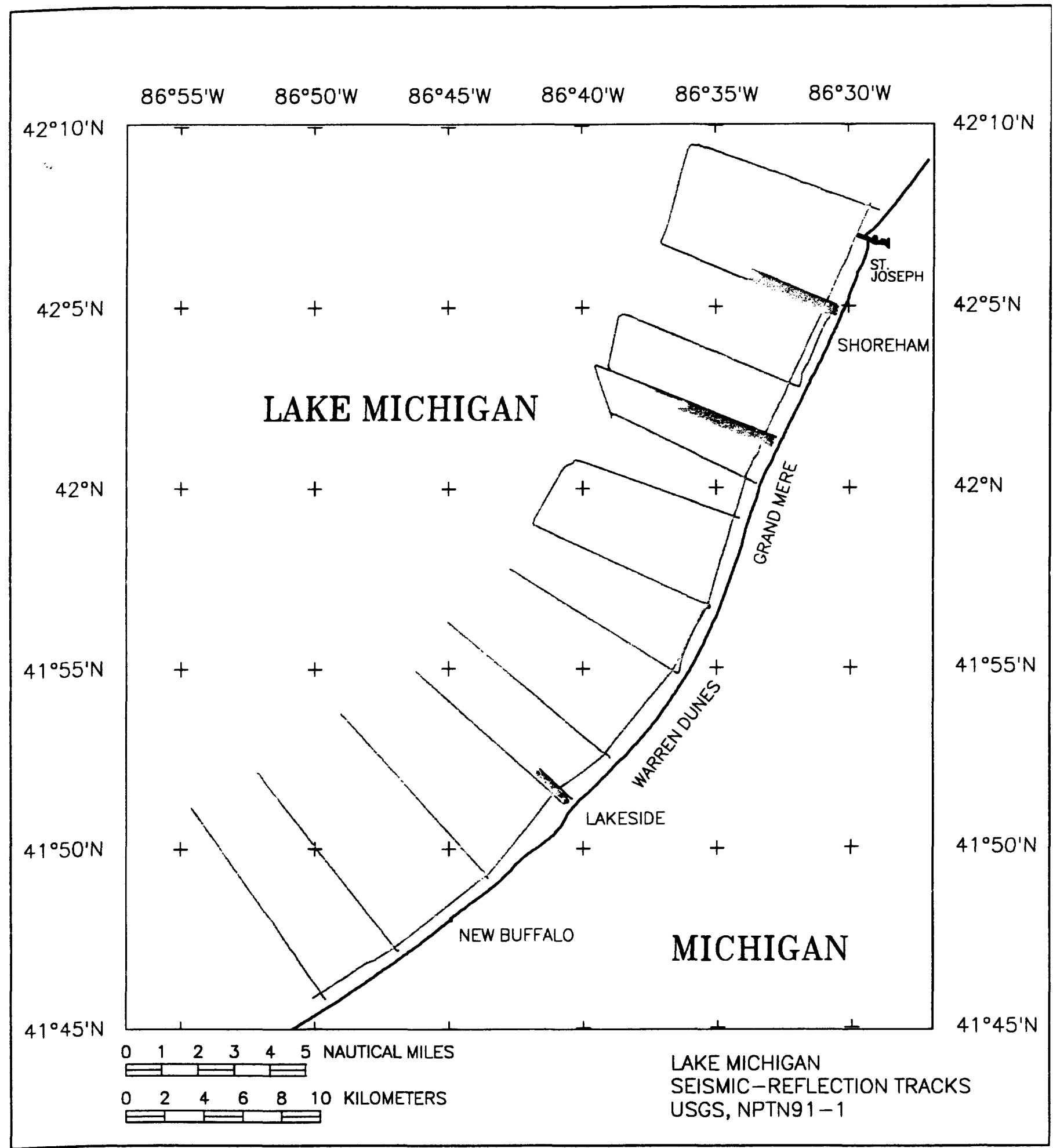

Figure 2. Tracklines along which USGS collected echo sounding, seismic reflection, and sidescan sonar data in 1991. In areas of solid red, sidescan mosaics were constructed. 


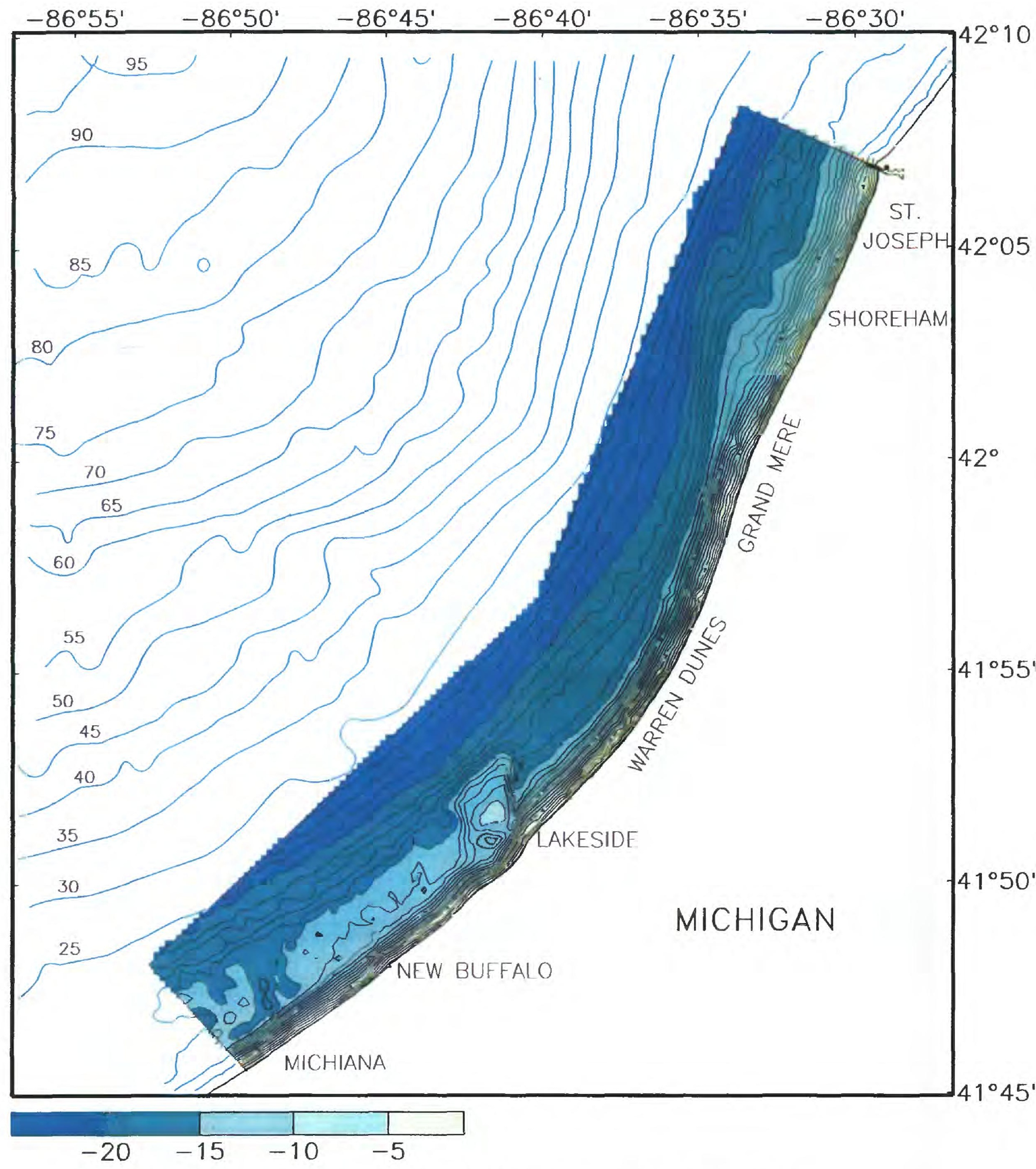

Figure 3. Bathymetric map interpreted from NOAA 1991 echo sounding profiles. One meter contour interval, shades of blue show 5 meter depth intervals. Blue bathymetric contour lines ( 5 meter interval) taken from previous surveys. 
NOS 1991 ACOUSTTC BATHYMETRY - NEAR NEW BUFFALO, MICHIGAN

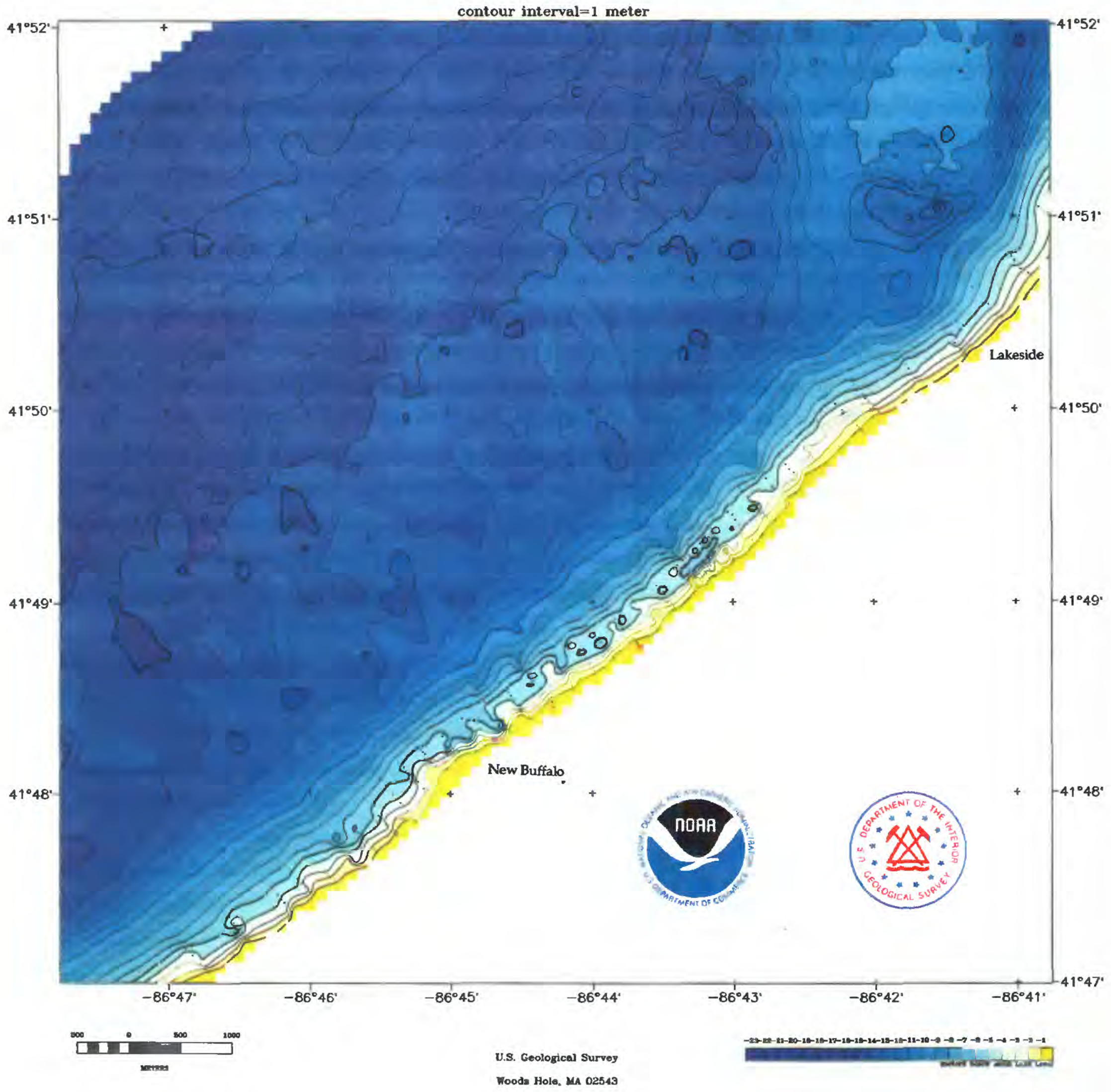

Figure 4. Larger scale view of NOAA 1991 acoustic bathymetry from Lakeside, Michigan south to the Michigan-Indiana border. Contour and depth shading interval is one meter. 
TERRA SURVEYS 1991 LASER BATHYMETRY - NEAR NEW BUFFALO, MICHIGAN

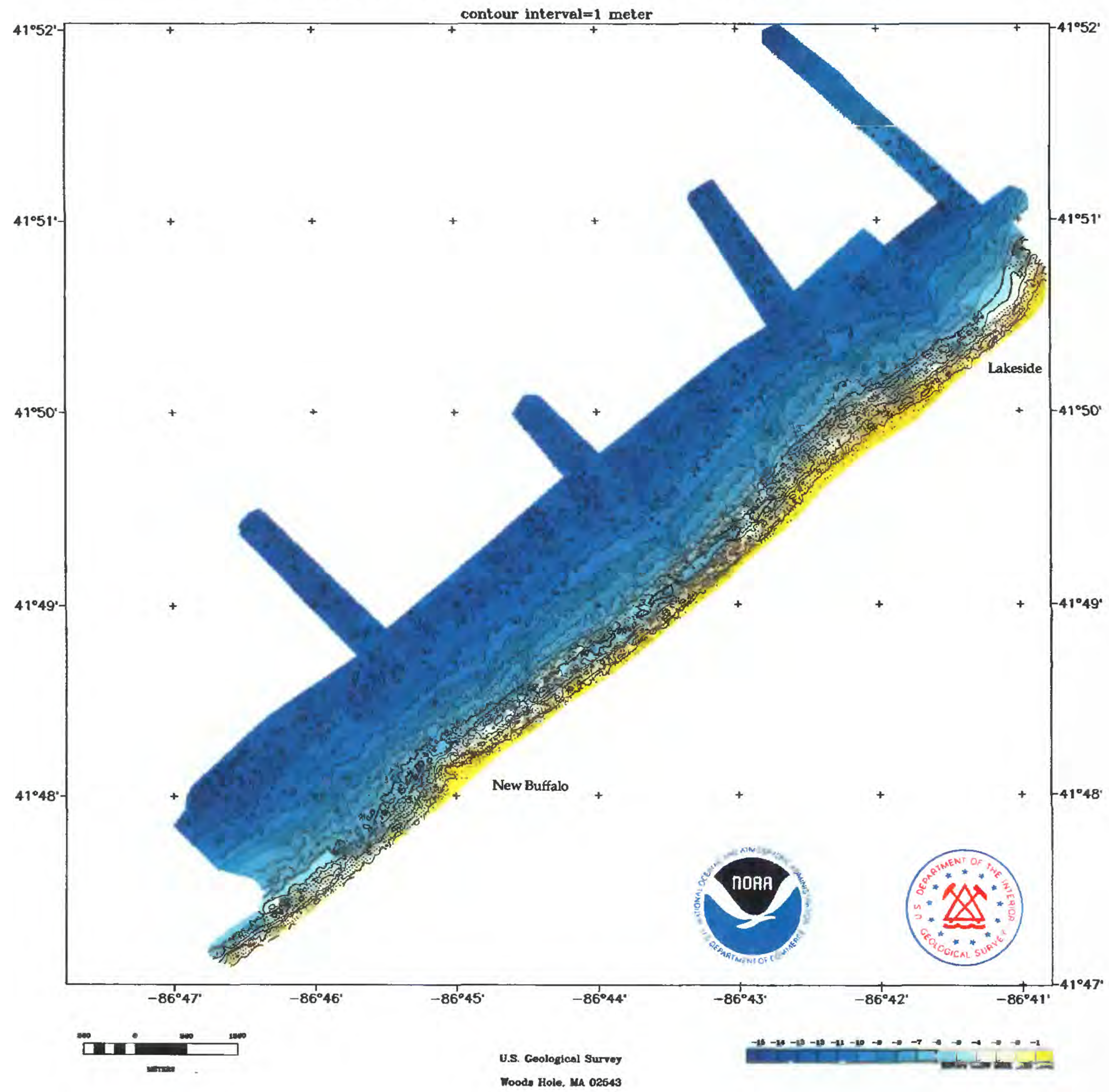

Figure 5. 1991 bathymetry in the same area as shown in previous map (fig. 4). Measurements taken by airborne laser instead of acoustics. The very high resolution of the technique reveals offshore sand bars and other features not resolved with acoustic data. 


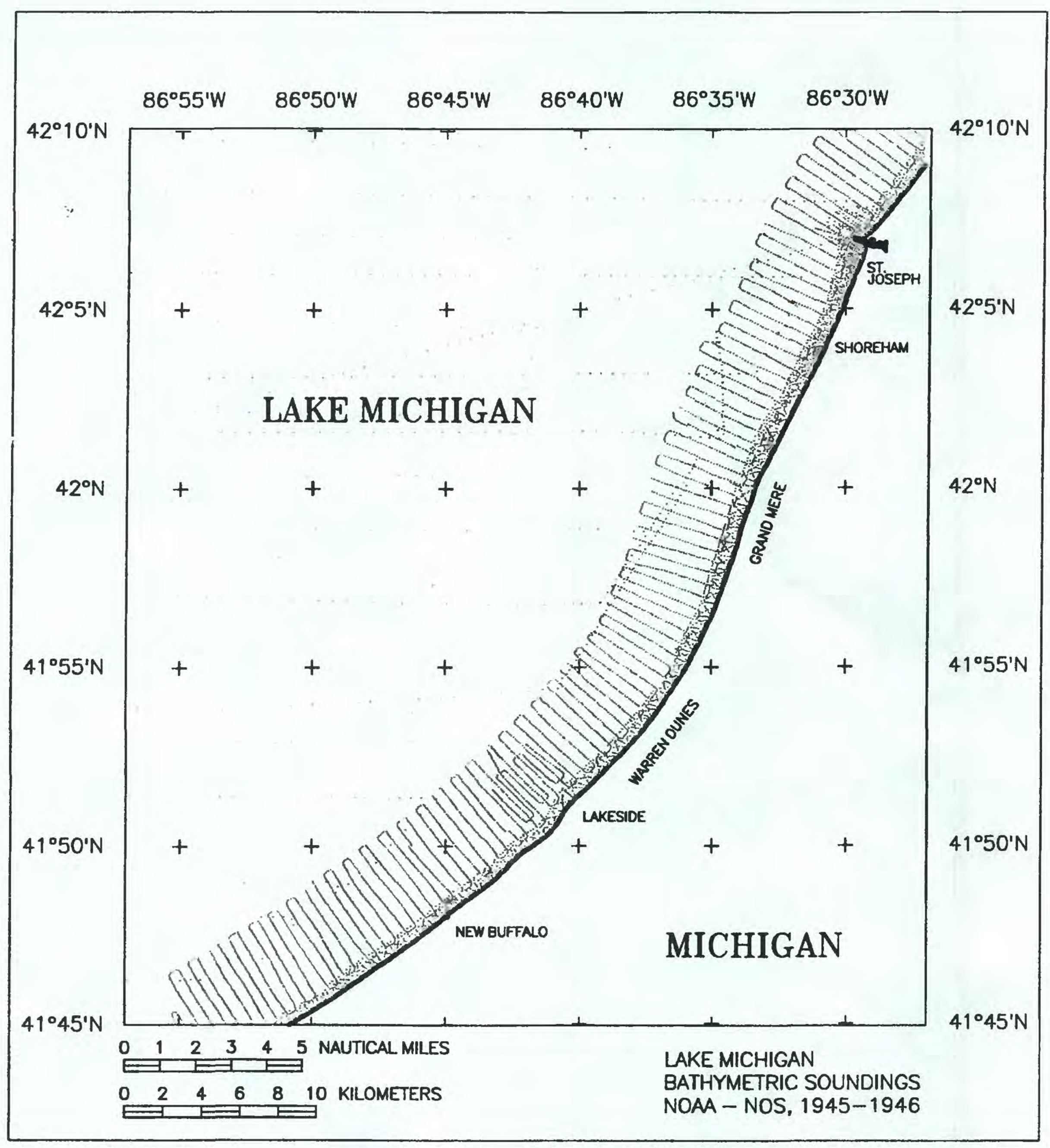

Figure 6. NOAA echo sounding profiles collected in 1945-46. This data set is compared to the NOAA 1991 bathymetric data in figures 8,10 , and 11 . 


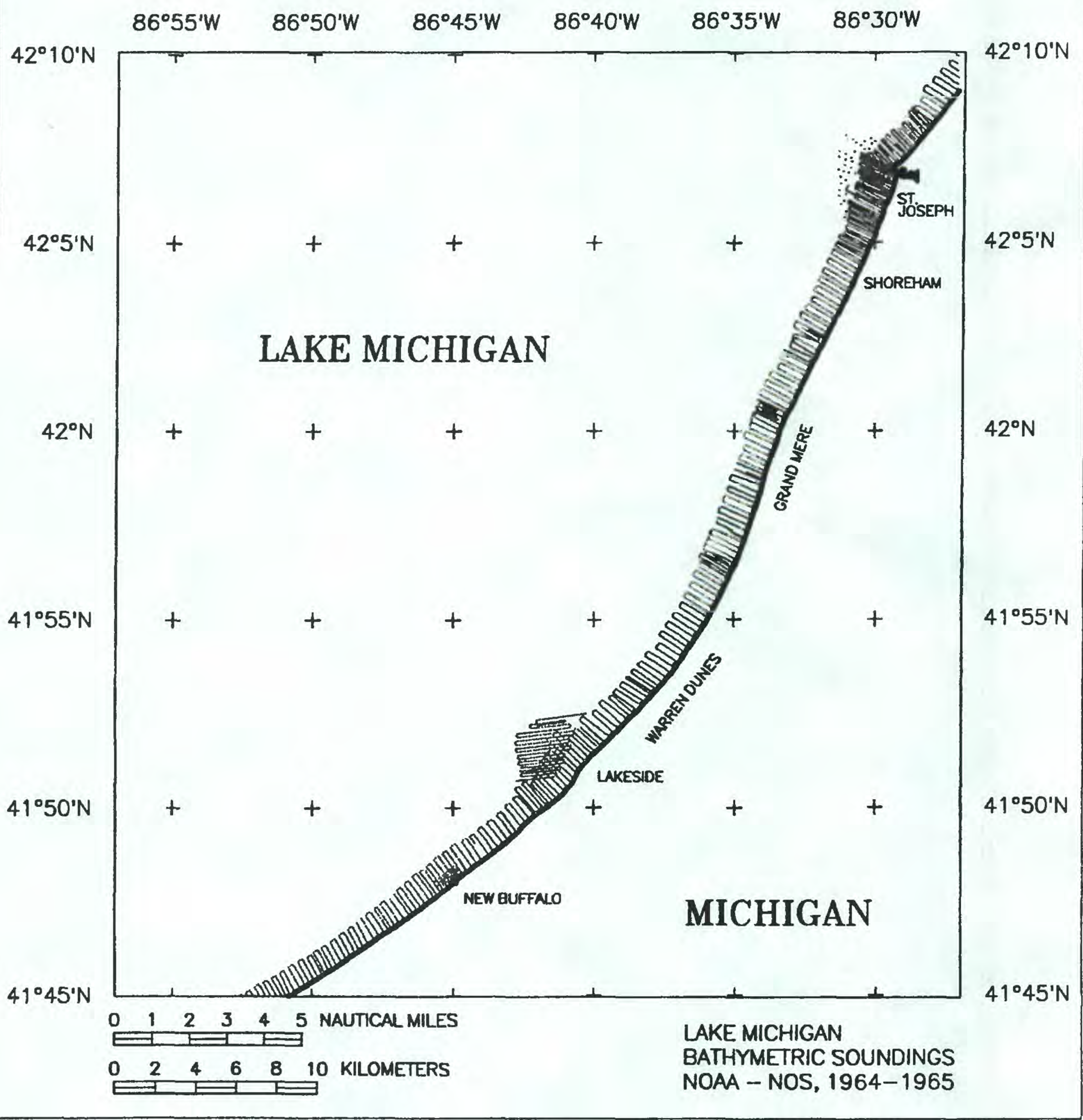

Figure 7. NOAA echo sounding tracklines collected in 1964-1965.

This data set is compared with both the 1945-46 data and the 1991 data in figures 8 and 9 . 


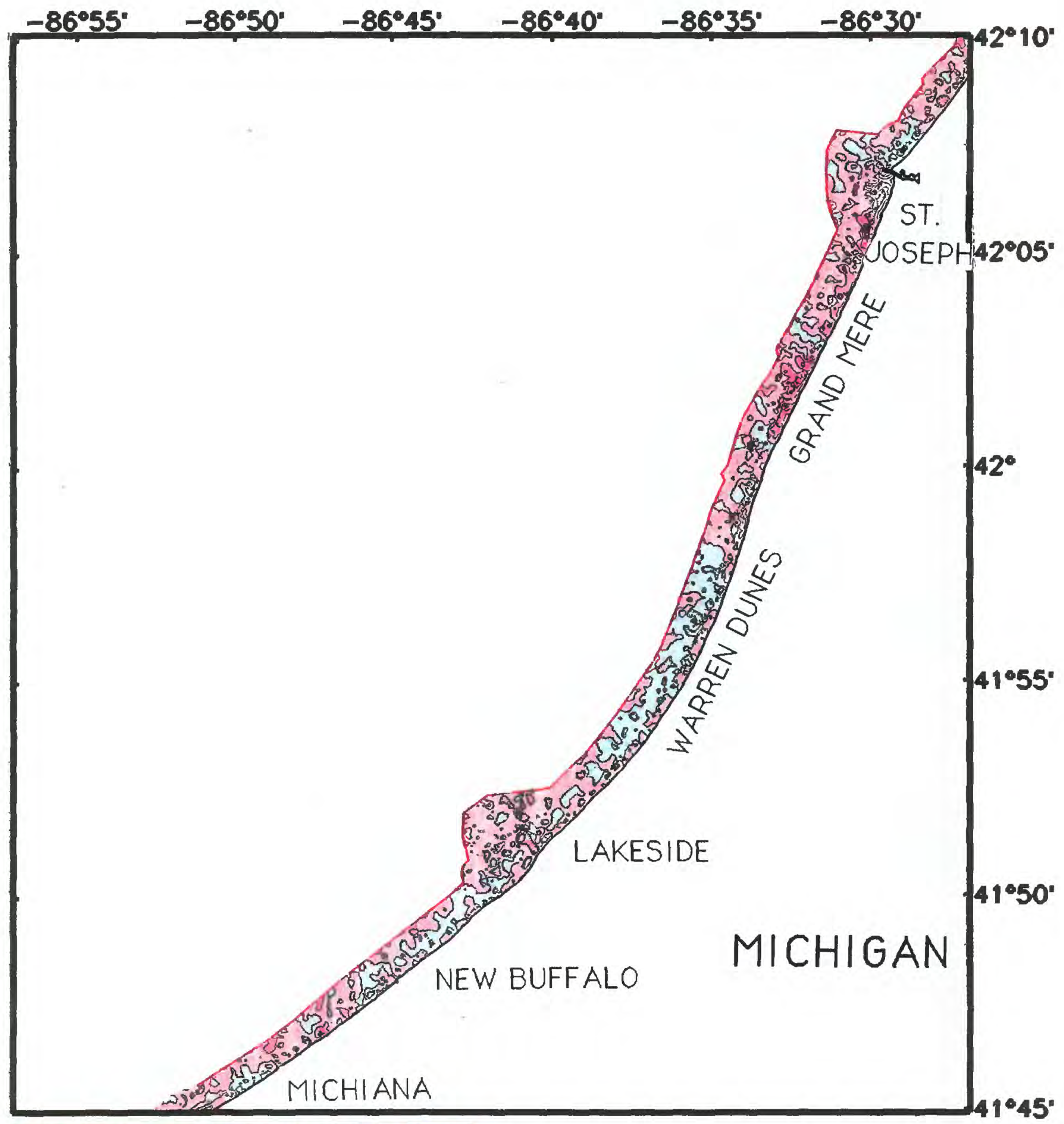

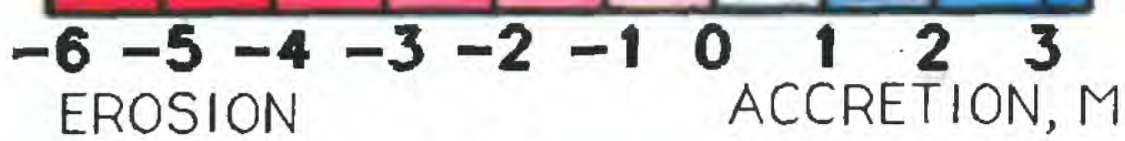

Figure 8. Difference in lake depth between the NOAA 1945-46 and 1964-65 surveys. Warm colors show erosion of the lake floor; cool colors show accretion. 

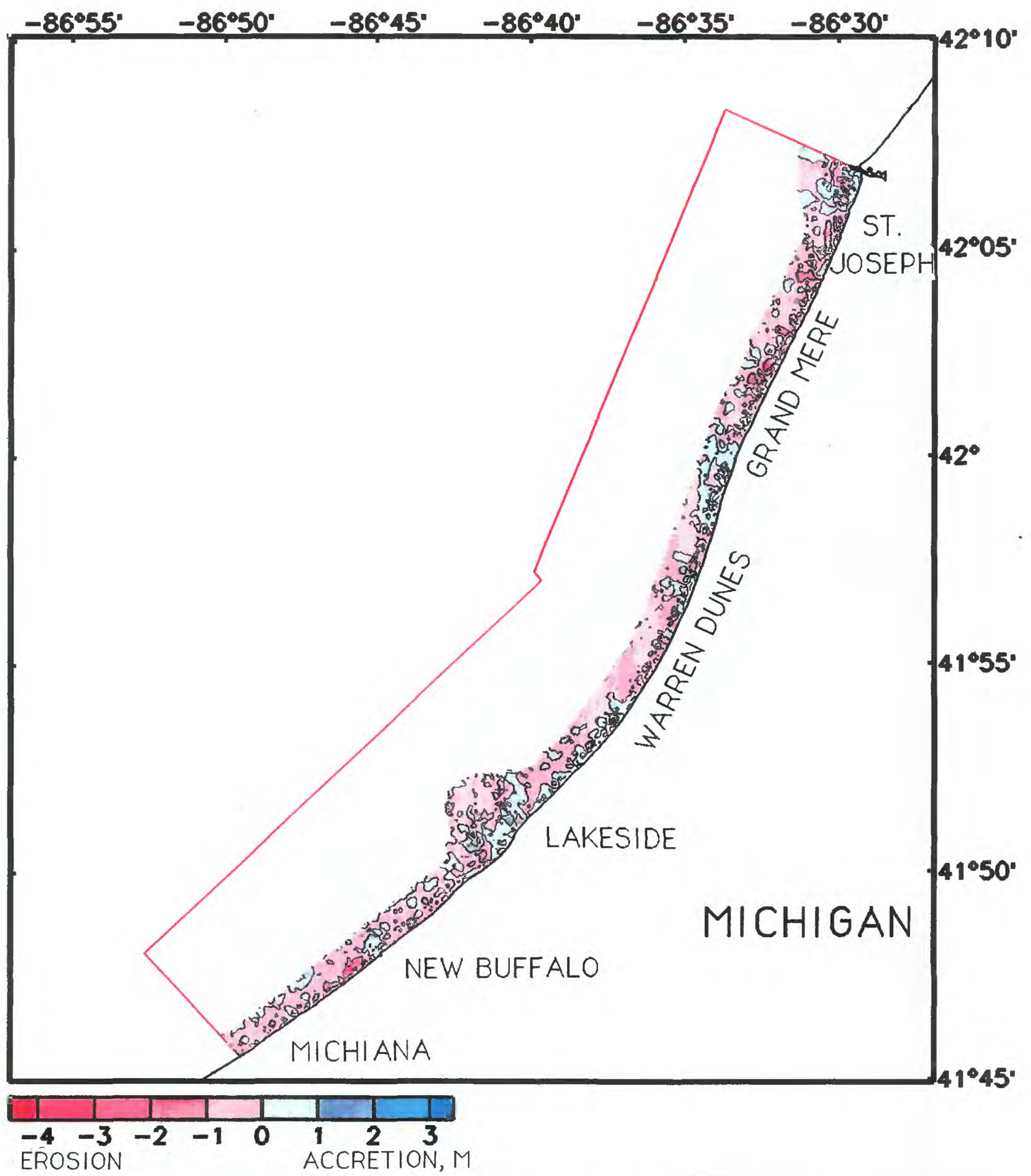

Figure 9. Difference in lake depth between the NOAA 1964-65 and 1991 surveys. Warm colors show erosion of the lake floor; cool colors show accretion. 


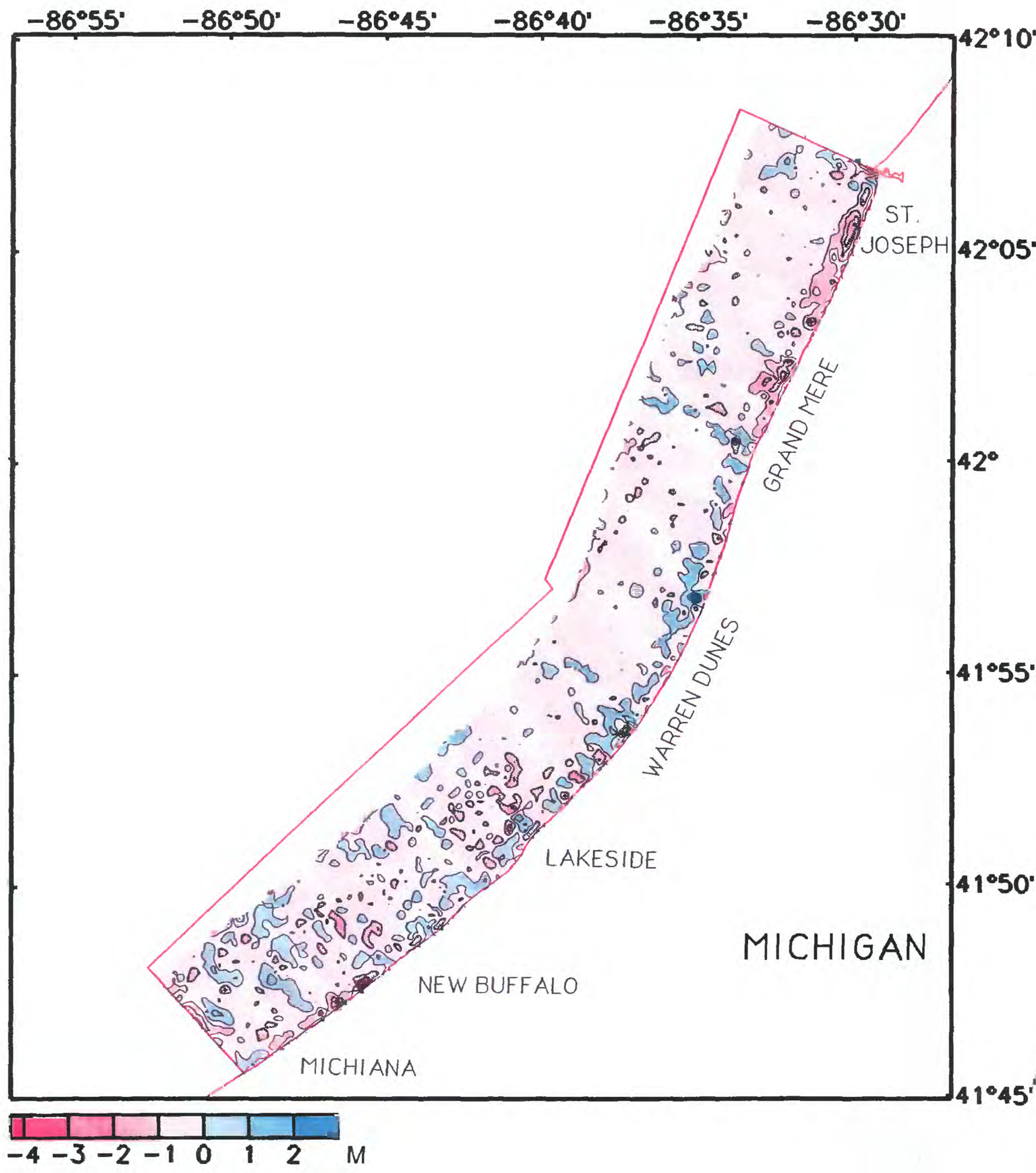

\section{EROSION ACCRETION}

Figure 10. Difference in lake depth between the NOAA 1945-46 and 1991 surveys. Warm colors show erosion of the lake floor; cool colors show accretion. Nearshore erosion is concentrated south of St. Joseph and New Buffalo, MI, where harbor jetties disrupt the net southerly littoral sand transport. 


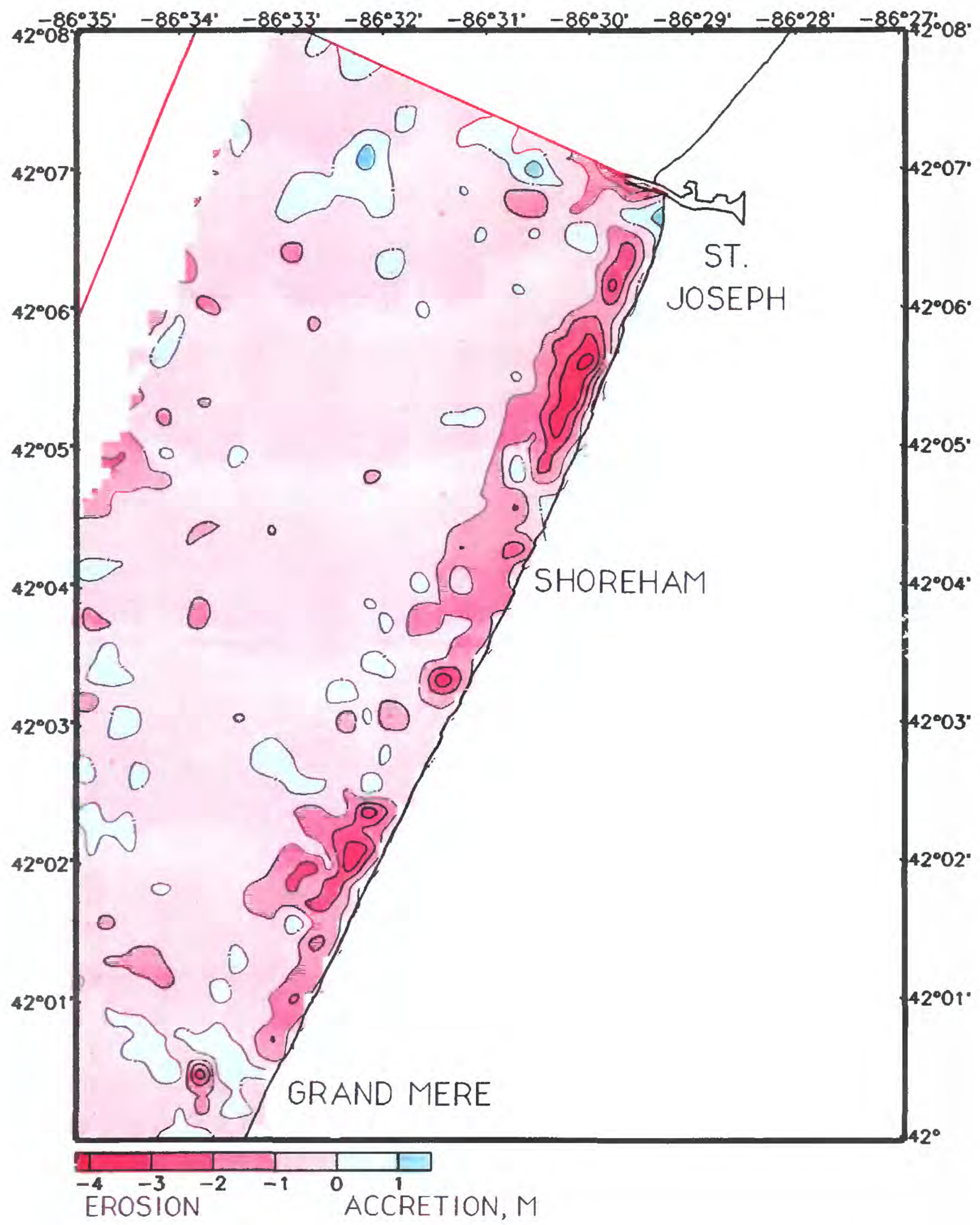

Figure 11. Detail of the St. Joseph-Shoreham area from the previous map (fig. 8). Difference in depth between NOAA 1945-46 and 1991 surveys. Warm colors show erosion; as much as 4 vertical meters of lake bed have been removed by erosion south of St. Joseph. 


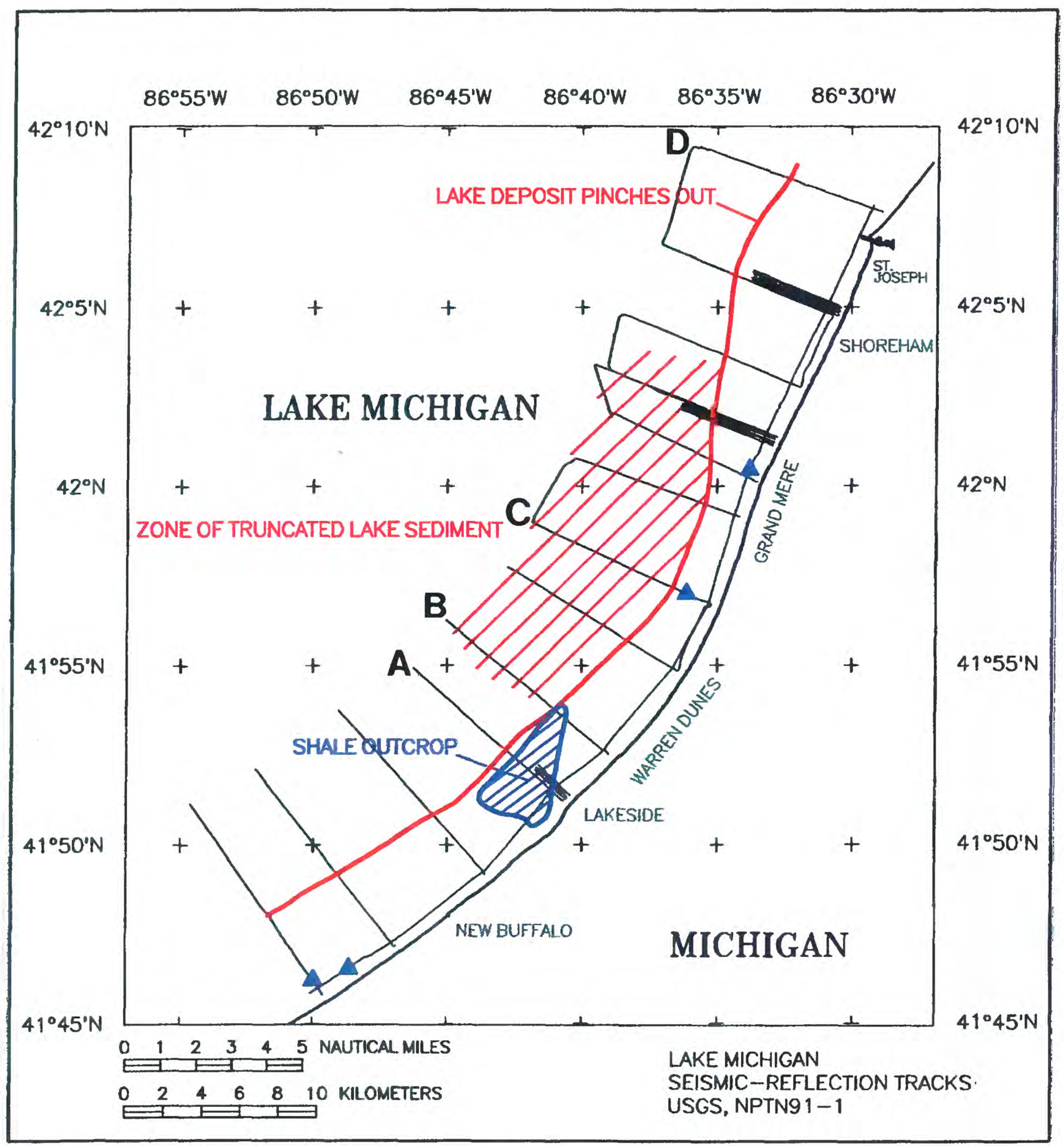

Figure 12. Interpretation of USGS seismic reflection survey. The blue hachured area (bedrock) is where shale crops out on the lake bed and blue triangles indicate less extensive exposures of shale. Offshore lake deposits pinch out along the red line. Red hachures show an area where lake sediments are truncated by erosion. 
WEST

NPTN91-1 LINE 4

Distance (kilometers)

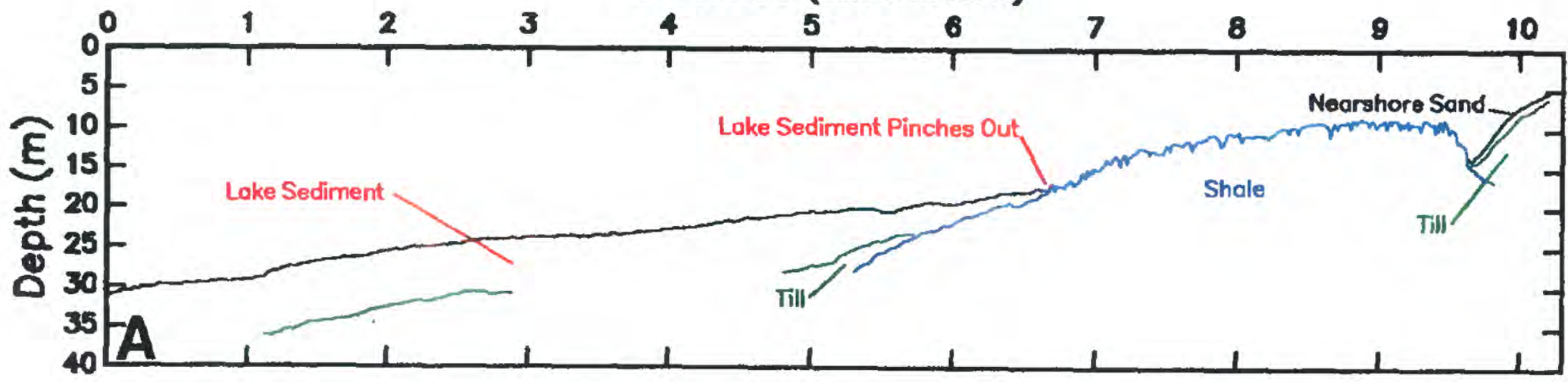

EAST

NPTN91-1 LINE 5

WEST

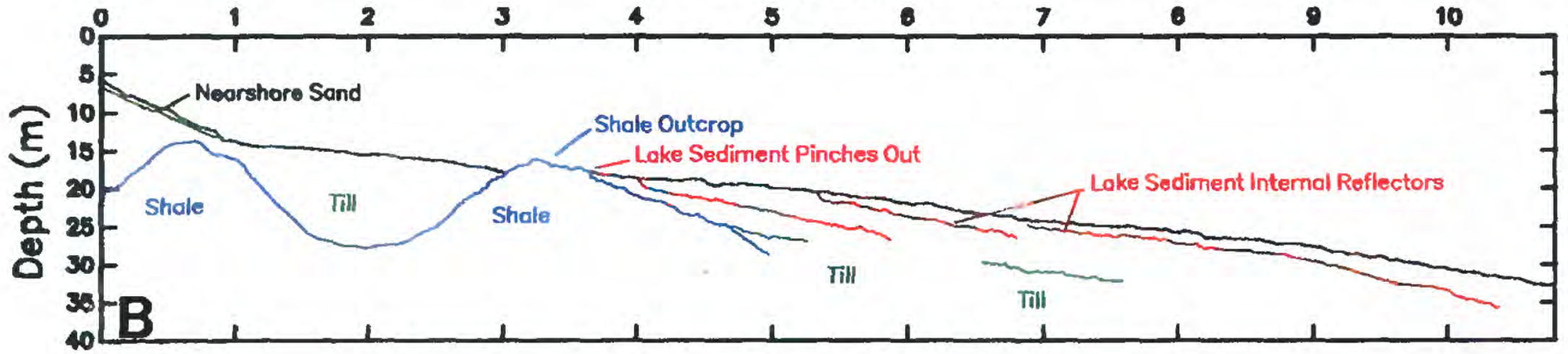

NPTN91-1 LINE 8

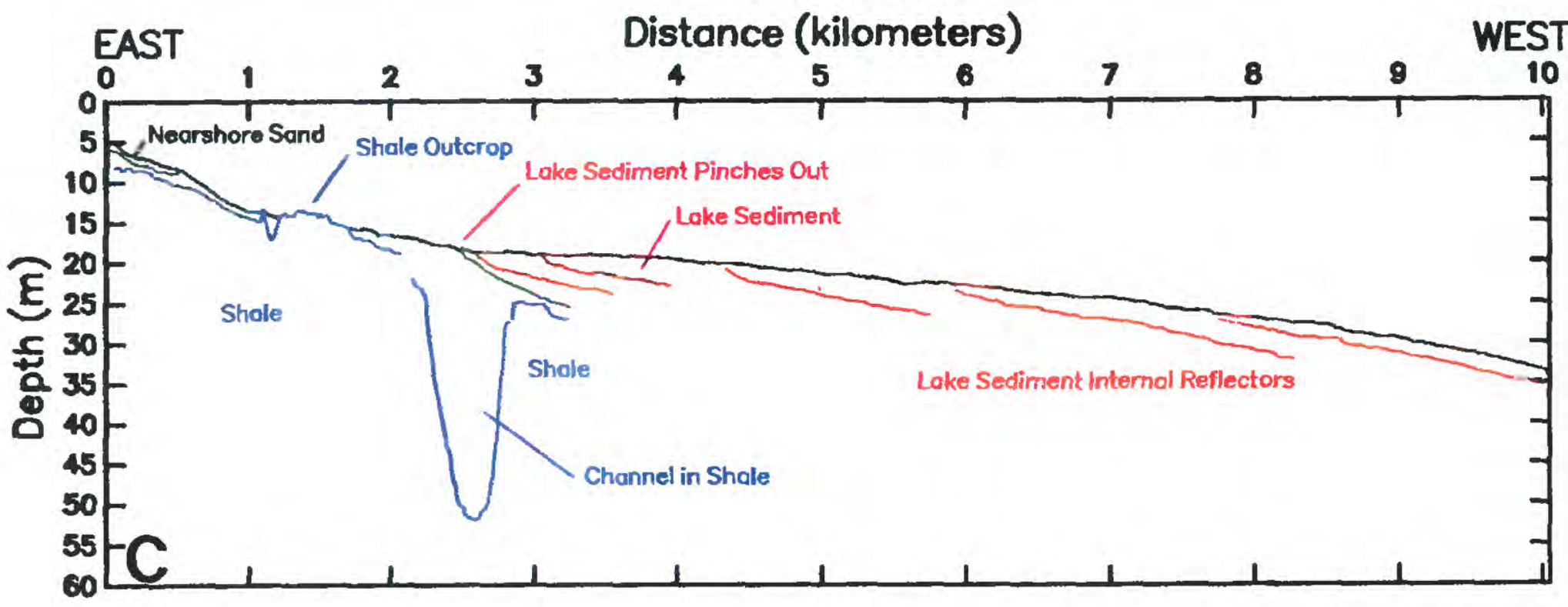

WEST

NPTN91-1 LINE 17

EAST

Distance (kilometers)

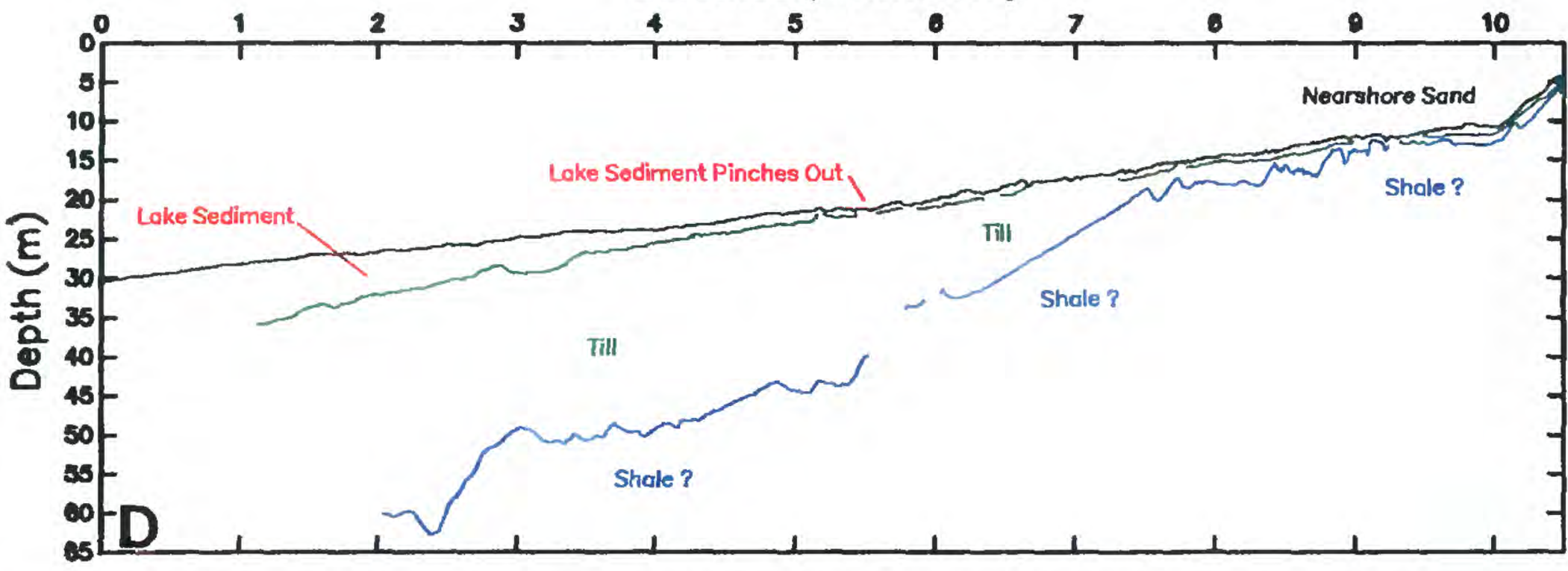

Figure 13. Geologic cross-section of selected profiles based on seismic reflection data, showing the stratigraphy of lake sediments, bedrock (shale), till, and nearshore sand. 


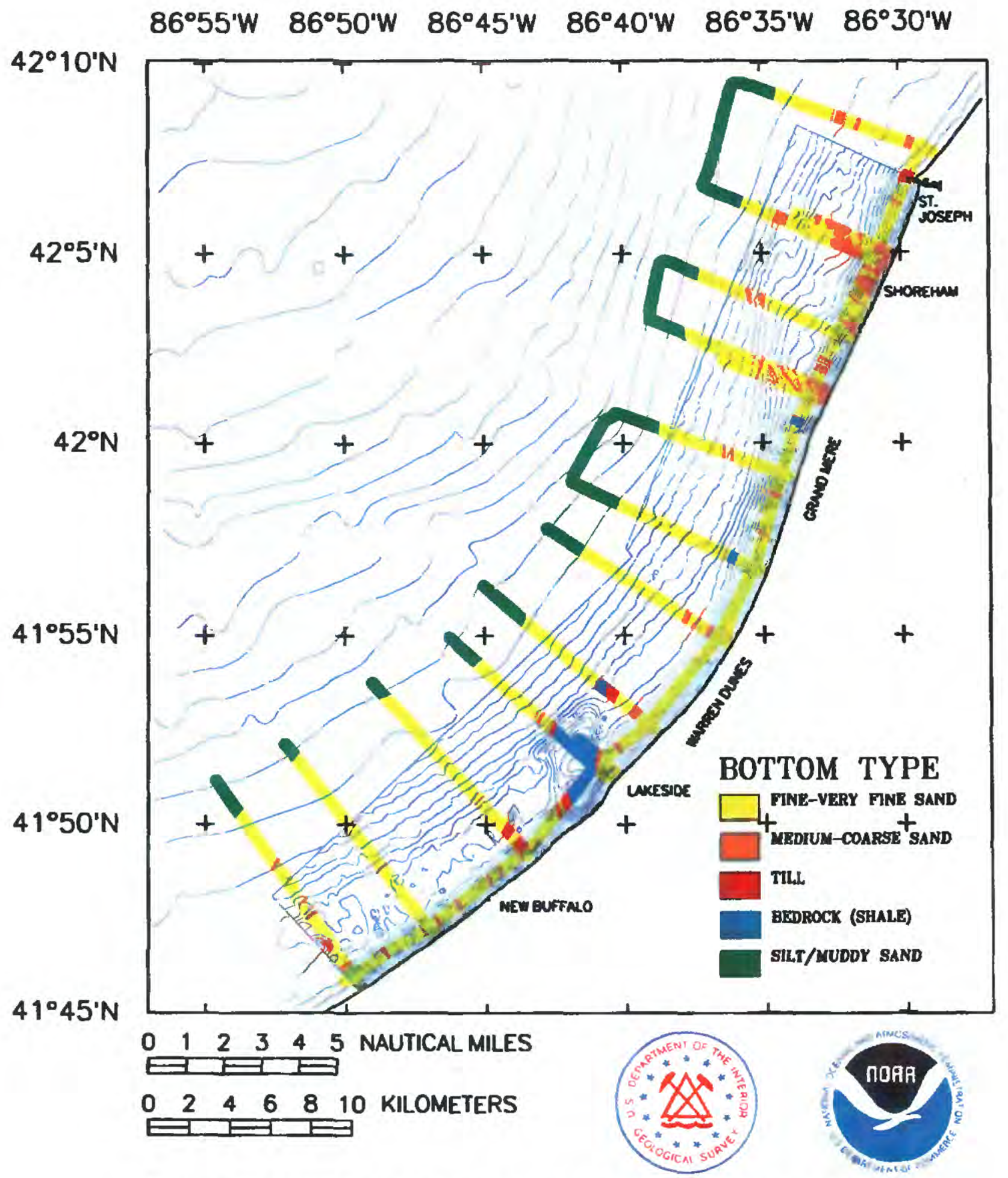

Figure14. Map of the southwestern shoreline of Michigan showing bottom sediment type based on interpretation of 1991 NOAA bathymetric, USGS sidescan sonar, and sediment sample data. Sand cover is thin or patchy. between St. Joseph and Grand Mere, MI. Till and lag gravel deposits are exposed on the lake floor. A comparison of NOAA 1945 and 1991 bathymetric data confirm that this area has undergone significant lake bed erosion. 


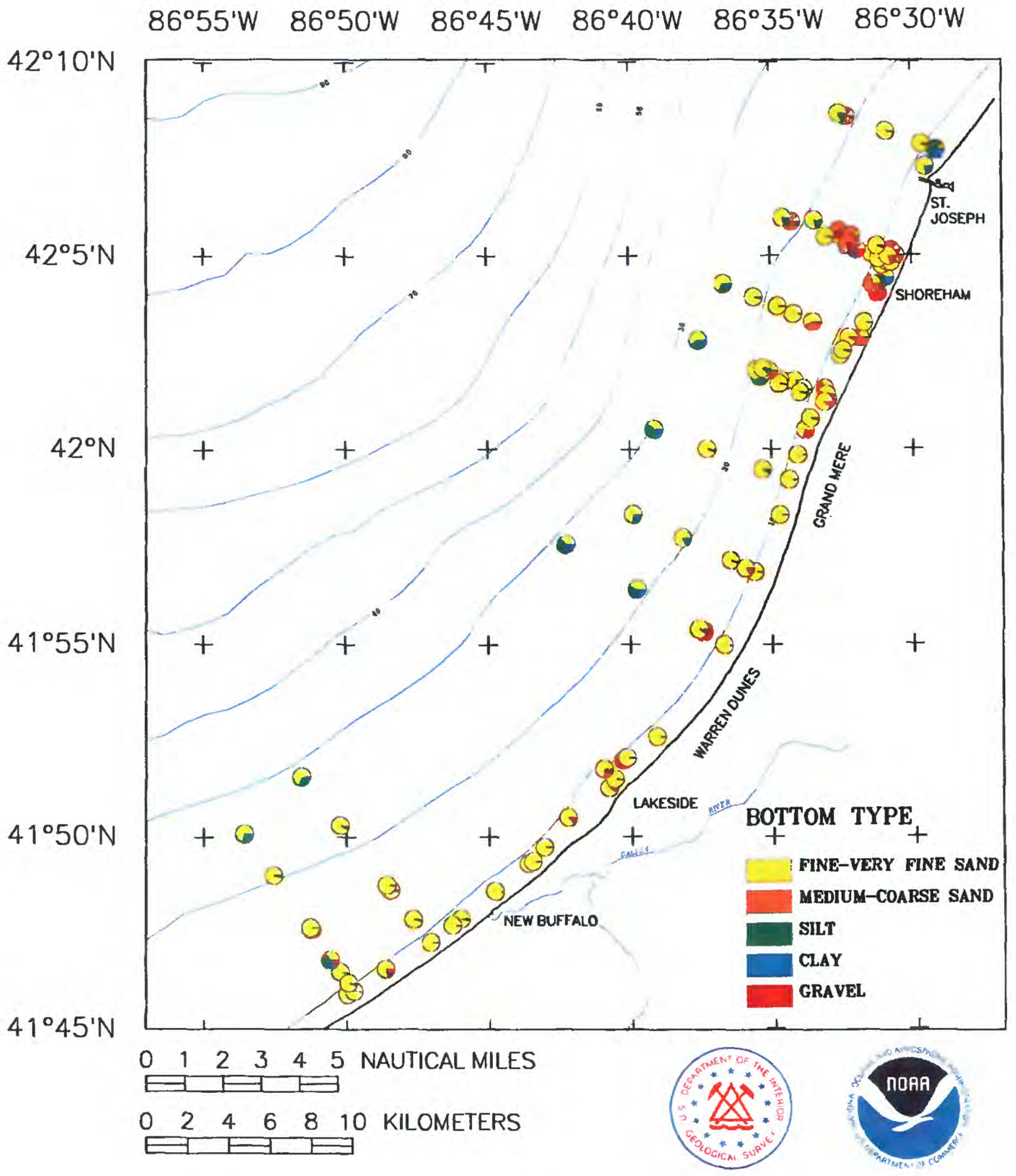

Figure 15. Locations where bottom sediment samples were collected in 1991 to aid in the interpretation of sidescan sonar and seismic data; pie diagrams show sediment composition. 


\section{LAKE MICHIGAN LAKESIDE MOSAIC}

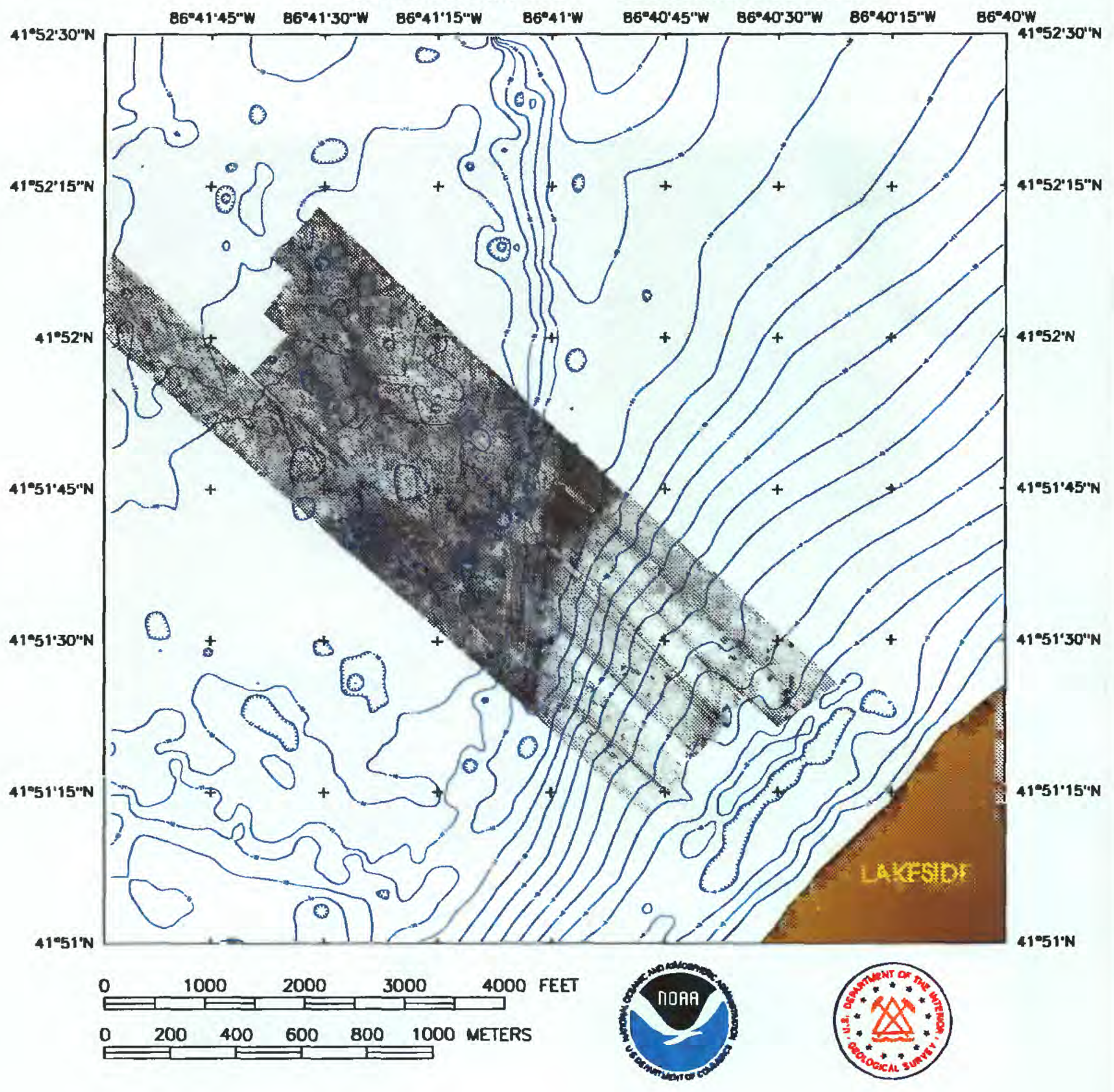

Foure 16. Sideecan acnar moaalc and detalled NOS 1991 bathymetry neer Lokealde, Michigan.

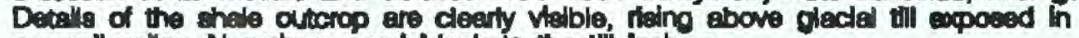

a small valley. Nearshore sand blankets the till inshore. 
LAKE MICHIGAN - LAKESIDE MOSAIC BATHYMETRY

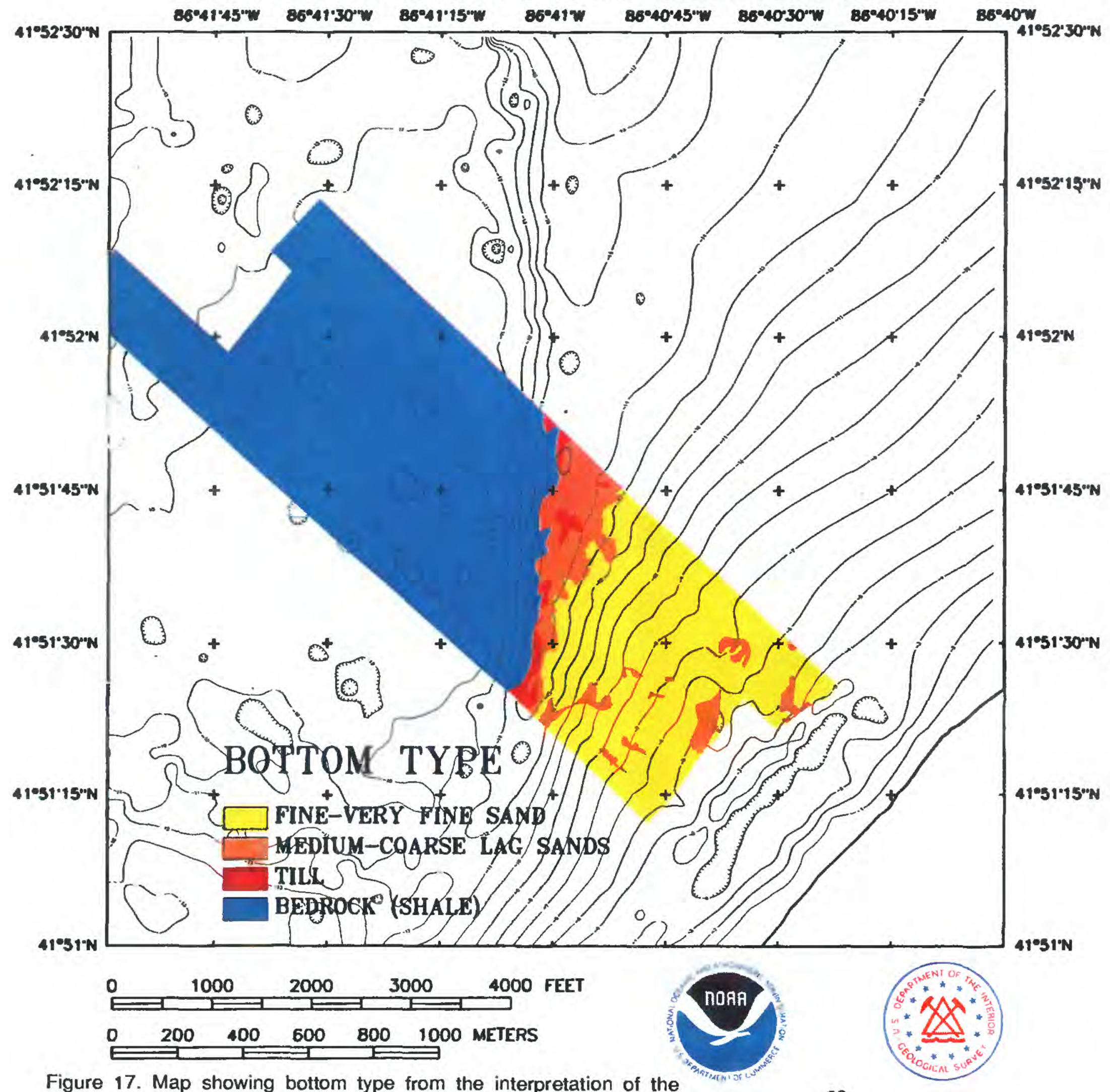
sidescan sonar mosaic and sediment samples near Lakeside, MI, with detailed bathymetry. 


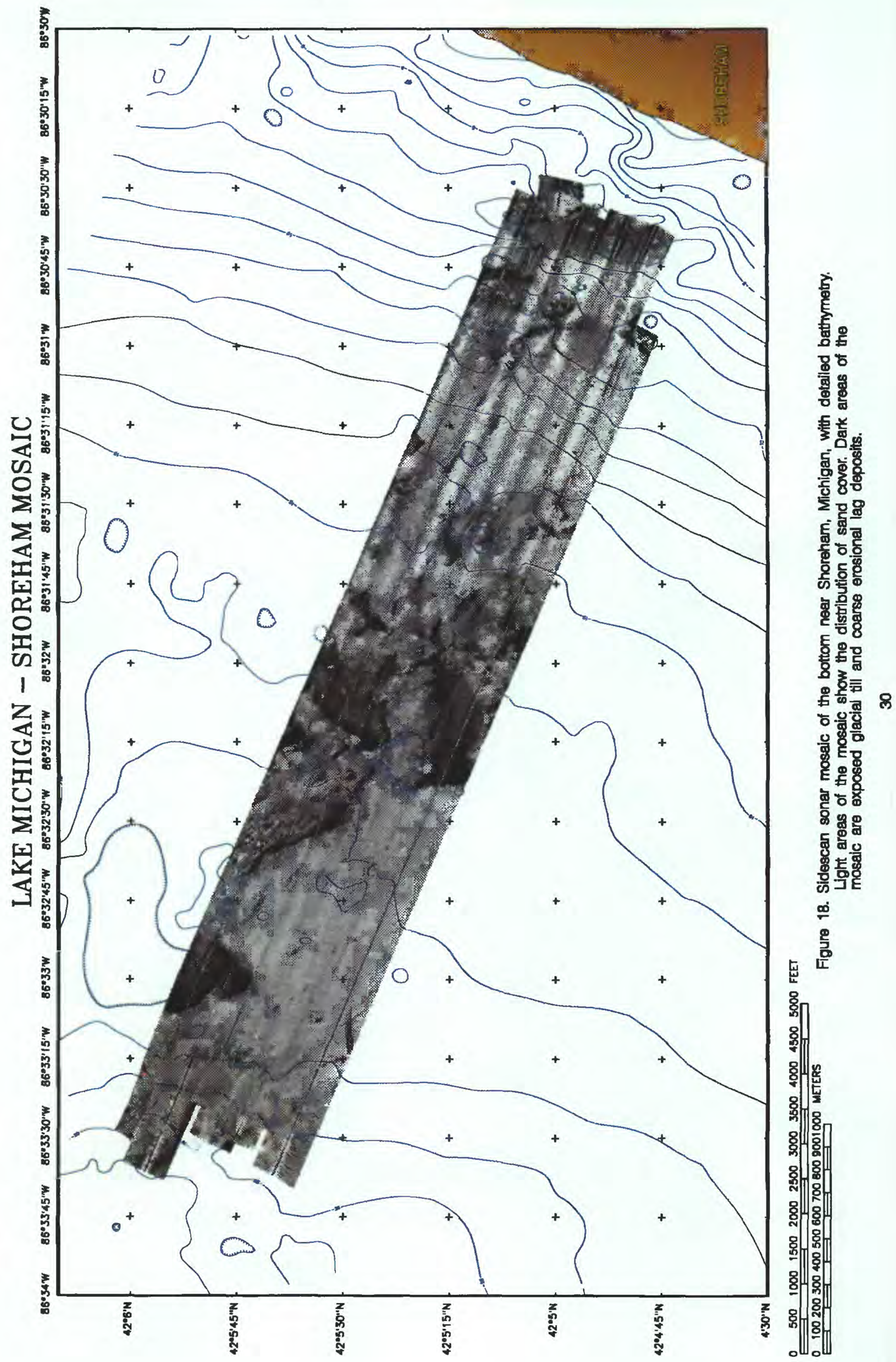




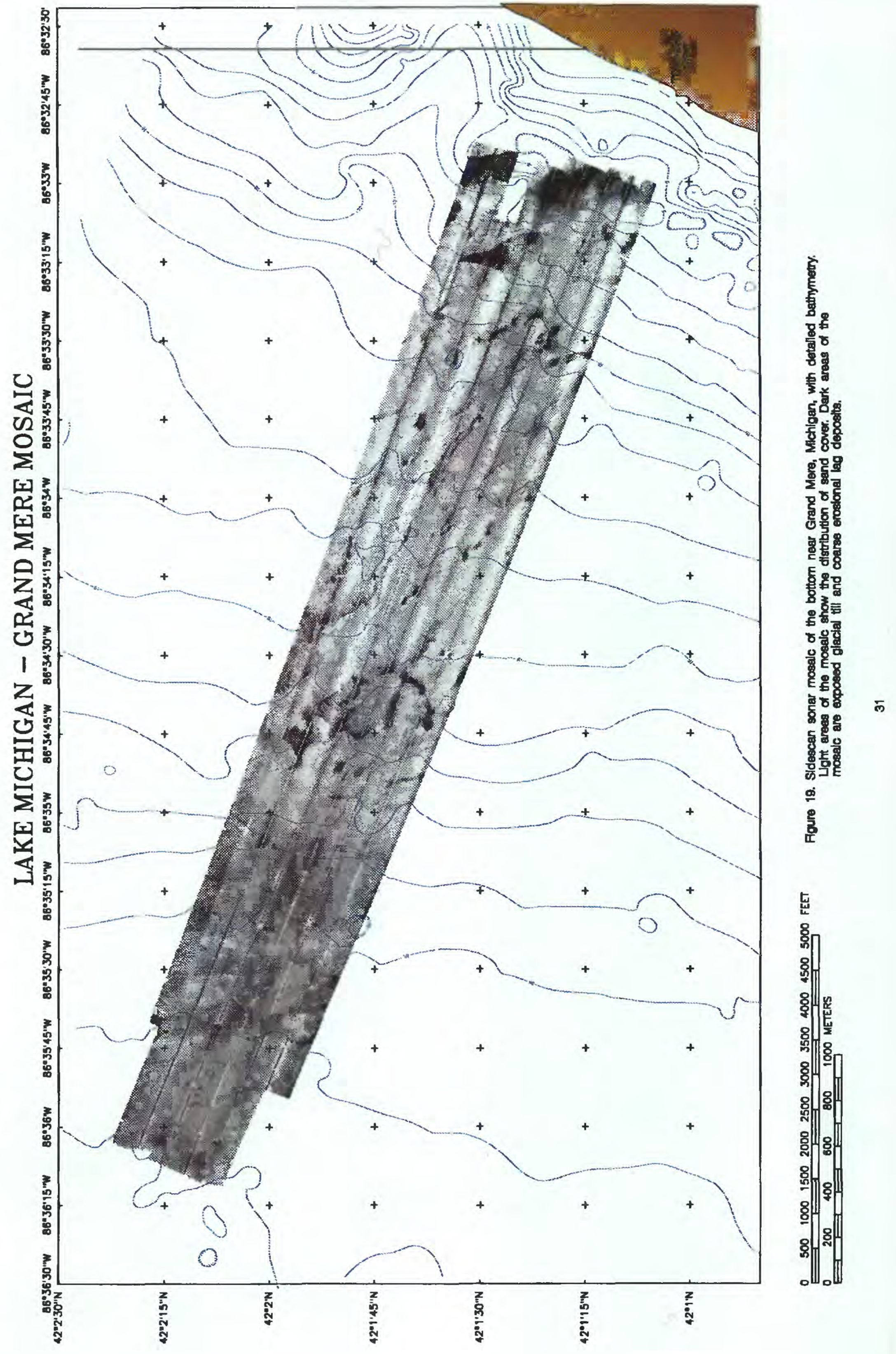




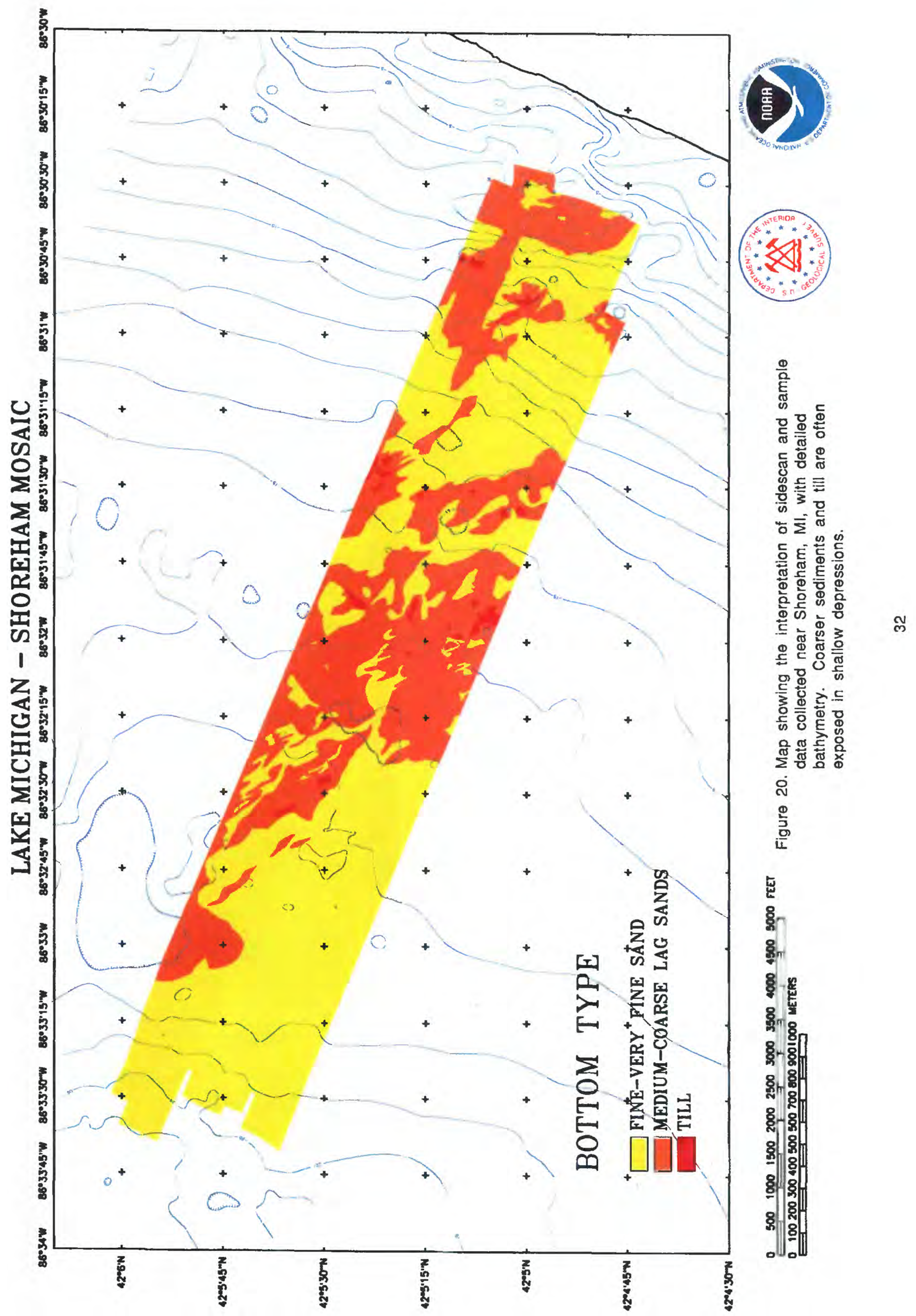




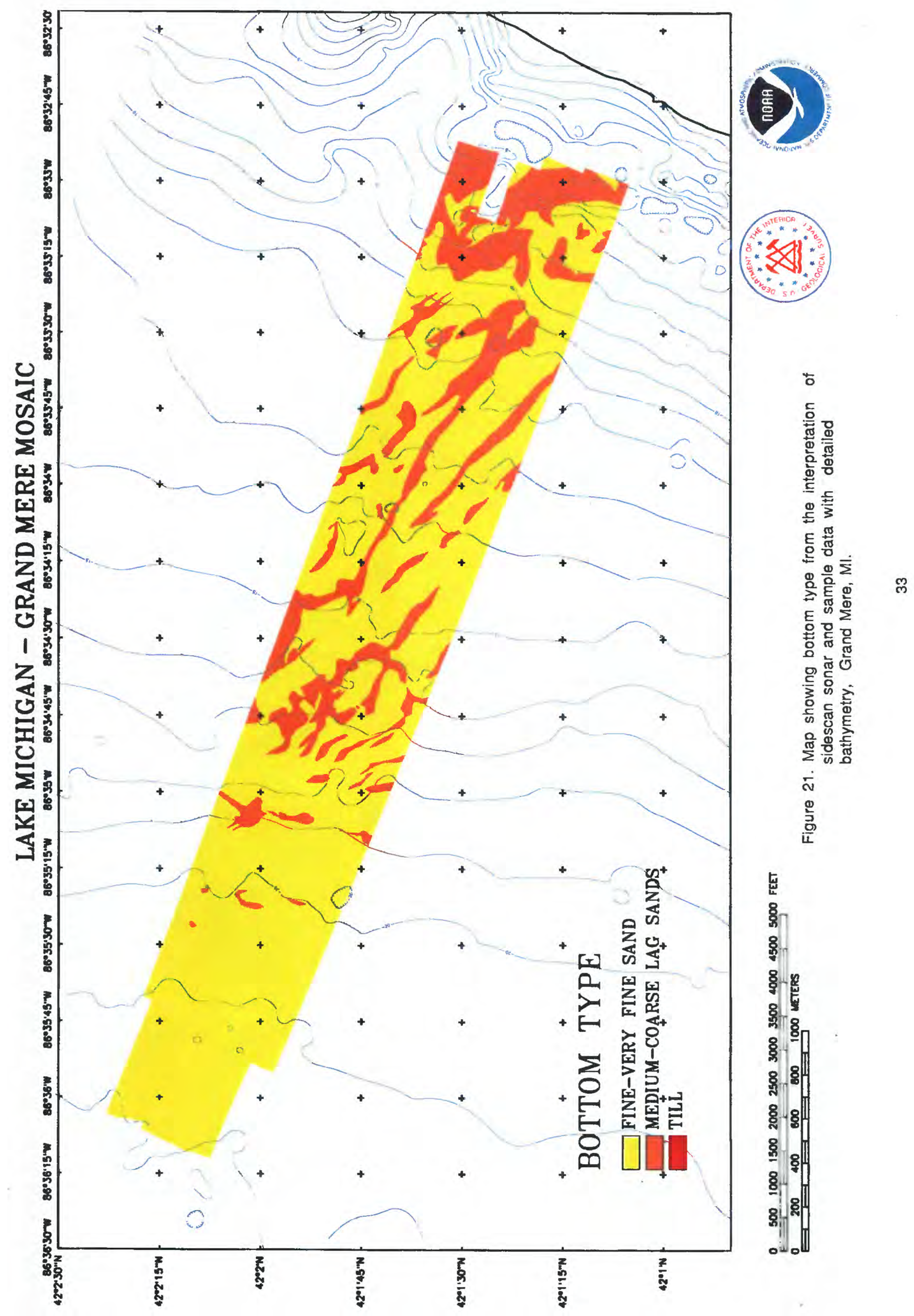


APPENDIX A

\begin{abstract}
AGENDA
1st ANNUAL WORKSHOP

REGIONAL GREAT LAKES MAPPING PROJECT

Fetzer Center

Western Michigan University

Kalamazoo, Michigan
\end{abstract}

March 17,1992

Purpose: To review work completed in 1991, to outline work to be carried out in 1992, and to discuss the longterm future of the project.

\title{
TUESDAY
}

March 17, 1992

$\begin{array}{lll}0900 & \text { Welcome } & \text { Tom Straw } \\ 0915 & \text { Agenda } & \text { Dave Folger } \\ 0930 & \begin{array}{l}\text { Introduction NOS } \\ \text { bathymetry and coastal } \\ \text { survey }\end{array} & \text { Denny Carroll }\end{array}$




\begin{tabular}{|c|c|c|}
\hline 0940 & Hydro data acquisition & Dean Seidel \\
\hline 1000 & Coffee Break & \\
\hline 1015 & Photogrammetry & Greg Fromm \\
\hline 1035 & Laser bathymetry & Jim Vosburgh \\
\hline 1100 & Discussion & \\
\hline 1115 & $\begin{array}{l}\text { Introduction geophysical } \\
\text { and geological surveys }\end{array}$ & Dave Folger \\
\hline 1125 & $\begin{array}{l}\text { Offshore bathymetry, } \\
\text { sediment distribution, } \\
\text { and stratigraphy }\end{array}$ & Dave Foster \\
\hline 1200 & Lunch at the Fetzer Center & \\
\hline 1300 & Ground penetrating radar & Bill Sauck \\
\hline 1320 & Nearshore storm effects & Guy Meadows \\
\hline 1340 & $\begin{array}{l}\text { Onshore Holocene and } \\
\text { Pleistocene sediment } \\
\text { distribution }\end{array}$ & Grahame Larson \\
\hline 1400 & Discussion of 1991 results & \\
\hline 1420 & $\begin{array}{l}\text { Corps of Engineers } 1991 \\
\text { studies }\end{array}$ & Larry Parson \\
\hline 1440 & $\begin{array}{l}\text { NOAA plan for } 1992 \\
\text { studies }\end{array}$ & Denny Carroll \\
\hline 1450 & $\begin{array}{l}\text { USGS plan for } 1992 \\
\text { studies }\end{array}$ & Dave Folger \\
\hline 1500 & Coffee Break & \\
\hline
\end{tabular}


1515 Discussion of 1992 plans

1600 Long-term future of the project

Denny Carroll and Dave Folger

1630 Discussion

1700 Adjourn 


\section{APPENDIX B}

\section{ATTENDEES}

1st ANNUAL WORKSHOP

REGIONAL GREAT LAKES MAPPING PROJECT

17 March 1992

Admiral Christian Andreasen

National Ocean Service

NOAA

11400 Rockville Pike

Rockville, Md. 20852

3014438321

Dr. David Barnes

Department of Geology

Western Michigan University

Kalamazoo, MI 49008-5150

6163875493

Mr. Thomas Bennett

Michigan Department of

Natural Resources

Steven T. Mason Bldg.

Box 30028

Lansing, MI 48909

5173731950

Dr. Stan Bolsenga

Great Lakes Environmental

Research Laboratory

2205 Commonwealth Blvd.

Ann Arbor, MI 48105-1593

$313 \quad 668 \quad 2234$ 
Mr. Michael Bricker

Michigan Geological Survey

Michigan Department of

Natural Resources

Steven T. Mason Bldg.

Box 30028

Lansing, MI 48909

5173346930

Mr. Dennis G. Carroll, Chief,

External Affairs

Mapping and Charting

Branch N/CG22

NOS, NOAA

6001 Executive Office Bldg

11400 Rockville Pike

Rockville, Md 20852

3014438157

Dr. Ronald B. Chase

Department of Geology

Western Michigan University

Kalamazoo, MI 49008-5150

616387550

Mr. Stephen Davis

Lake Michigan Specialist

Water Division

Indiana Department of Natural Resources

100 Water St.

Michigan City, IN 46360

2198748316 
Mr. Ted Doyle

Photogrammetry Branch

NOS, NOAA

6001 Executive Office Bldg.

Rockville, Md 20852

3014438405

Mr. Ron Erickson

Corps of Engineers

Detroit District

ATTN: CENCE-ED-L

P. O. BOX 1027

Detroit, MI 48231

3132262226

Mr. John Filkins

Evrronmental Protection Agency

9311 Groh Rd.

Grosse Ile, MI 48138

3136927600

Dr. David W. Folger

U. S. Geological Survey

Woods Hole, MA 02543

5084572234

Mr. David S. Foster

U. S. Geological Survey

Woods Hole, MA 02543

$\begin{array}{lll}508 & 4572271\end{array}$

Mr. Gregory Fromm

Photogrammetry Branch

NOS, NOAA

6001 Executive Office Bldg.

Rockville, Md 20852

3014438006 
Ms. Catherine L. Hill

Water Resources Division

U. S. Geological Survey

5957 Lakeville Blvd.

Indianapolis, IN 46278

$317290 \quad 3333$

Mr. Martin Jannereth

Michigan Department of

Natural Resources

Steven T. Mason Bldg.

Box 30028

Lansing, MI 48909

$\begin{array}{lll}517 & 373 \quad 1950\end{array}$

Mr. Charles Johnson

Corps of Engineers

North Central District

ATTN: CENCD-PE-TG

111 No. Canal St.

Chicago, IL 60606

3123530584

Mr. Vincent G. Johnson

Evrronmental Protection Agency

9311 Groh Rd.

Grosse Ile, MI 48138

3136927600

Mr. Jon Jolly

Terra Surveys

1962 Mills Rd.

RR2

Sidney, B.C.

Canada V83S1

2069384166 
Dr. Grahame Larson

Dept. of Geology

Michigan State University

East Lansing, MI 48824-1115

5173554626

Mr. Richie Laton

Dept. of Geology

Western Michigan University

Kalamazoo, MI 49008-5150

6163875485

Dr. Jay Martin

Bowling Green State University

Bowling Green, Ohio 43403

4193523250

Dr. Guy Meadows

Naval Architecture and

Mechanical Engineering

University of Michigan

Ann Arbor, MI 48109

3137645235

Mr. Thomas O'Bryan

Corps of Engineers

Grand Haven Projects Off

P. O. Box 629

Grand Haven, MI 49417

6168425510

Mr. Larry Parson

Waterways Experiment

Station

ATTN: CEWES-CD-SG

3909 Halls Ferry Road 
Vicksburg, MS 39180-6199

6016343007

Mr. Charles Pistis

County Extension Office

Michigan Sea Grant Ext.

333 Clinton St.

Grand Haven, MI 49417

6168468250

Dr. William Sauck

Dept of Geology

Western Michigan University

Kalamazoo, MI 49008

$\begin{array}{lll}616 & 3874991\end{array}$

Mr. Dave Schweiger

Corps of Engineers

Detroit District

ATTN: CENCE-ED-L

P. O. Box 1027

Detroit, MI 48231

3132264886

Capt. Dean Seidel

Hydrographic Branch

NOS, NOAA

6001 Executive Office Bldg.

Rockville, Md 20852

3014438231

Mr. Mel Simpson

Corps of Engineers

Grand Haven Projects Off

P. O. Box 629

Grand Haven, MI 49417

6168425510 


\begin{abstract}
Ms. Anne Smith
Corps of Engineers

Chicago District
\end{abstract}

ATTN: CENCC-ED-G

111 No. Canal St.

Chicago, IL 60606

3123536517

Dr. Marian Smith

Department of Geology

Western Michigan University

Kalamazoo, MI 49008-5150

6163757111

Dr. William A. Smith

Department of Geology

Western Michigan University

Kalamazoo, MI 49008-5150

6163875497

Mrs. Joyce Stedt

Indiana Dunes National Lakeshore

National Park Service

1100 No. Mineral Springs Road

Porter, IN 46304

2199267561

Professor W. Thomas Straw, Chair

Department of Geology

Western Michigan University

Kalamazoo, MI 49008-5150

6163875485

Mr. Charles Thompson

Corps of Engineers

Detroit District 
ATTN: CENCE-ED-D

P. O. Box 1027

Detroit, MI 482312

3132266792

Dr. Todd Thompson

Indiana Geological Survey

611 North Walnut Grove

Bloomington, Indiana 47405

8128554400

Dr. Brian Trask

Illinois Geological Survey

Natural Resources Building

615 East Peabody Drive, Room 121

Champaign, IL 61820

2172442421

Mr. Jim Vosburgh

Terra Surveys

1962 Mills Rd.

RR2

Sidney, B.C.

Canada V83S1

6046560931

Mr. Ken Vrana

Michigan Sea Grant

333 Natural Resources Bldg.

Michigan State University

E. Lansing, MI 48824

5173539735

David Wardwell

Dept. of Geology

Western Michigan University

Kalamazoo, MI 49008-5150

6163875485 
Dr. William L. Wood

Great Lakes Coastal

Research Laboratory

School of Civil Engineering

Purdue University

West Lafayette, IN 47907-1284

3174942178 


\title{
APPENDIXC
}

\section{Acknowledgments}

\begin{abstract}
We wish to acknowledge the able assistance of D. Blackwood, B.
Irwin, K. Parolski, R. Tagg, and J. Zwinakis, during the many phases of this project.
\end{abstract}

